\title{
Seismic behavior assessment of a Brazilian heritage construction
}

\author{
Francisco Brandão, Aldecira Diógenes
}

GEM/UVA, Department of Civil Engineering, State University of V ale do Acaraú, Brazil

eng.fsbrandao@gmail.com, bttp://orcid.org/0000-0001-7888-6321

aldeciragd@yahoo.com.br,https://orcid.org/0000-0002-1411-8718

João Fernandes

CENTRE/FAS, Department of Civil Engineering of the Faculty Ari de Sá, Brazil

j.fernandes.e@@outlook.com, bttp:/ / orcid.org/0000-0002-4051-890X

Esequiel Mesquita

Nucle of Industrial Technology of Ceara and Department of Civil Engineering of the Faculty Ari de Sá, Brazil

mesquite.e@outlook.com, bttp:// orcid.org/0000-0001-9905-6220

Michele Betti

DICE A, Department of Civil and Environmental Engineering of the University of Florence, Italy

mbetti@dicea.unifi.it, bttp:/ /orcid.org/0000-0002-8389-3355

ABSTRACT. Preservation of historical constructions, and passing it on to future generations, is a major issue in modern societies. Earthquakes are one of the major causes of damages to heritage buildings across the world. The city of Sobral (Ceará State, Brazil) keeps in its historic center a large number of heritage buildings and, since 2008, an intense seismic activity has been observed. This study aims to contribute to the preservation of the Sobral heritage constructions against seismic loads through the assessment of the seismic behavior of one representative building: the Nossa Senhora das Dores Church, a $19^{\text {th }}$ century historical construction. First, a 3D finite element (FE) model was built and tuned according to the results of dynamic tests performed under environmental loads. Next, the FE model was employed to assess the seismic behavior of the church by performing linear time-history analyses employing two real earthquakes. The results showed big displacements and high stresses in many parts of the church, allowing to identify the most critical and most susceptible to damage areas (based on the seismic scenarios considered). These results can be considered as a support for seismic retrofitting measures to be adopted on Sobral heritage constructions.

KEYwORDS. Seismic behavior; Heritage construction; Nossa Senhora das Dores Chuch; Numerical simulation; Sobral.

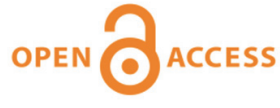

Citation: Brandão, F., Diógenes, A., Fernandes, J., Mesquita, E., Betti, M., Seismic behavior assessment of a Brazilian heritage construction, Frattura ed Integrità Strutturale, 45 (2018) 14-32.

Received: 05.04 .2018

Accepted: 03.06.2018

Published: 01.07.2018

Copyright: (C) 2018 This is an open access article under the terms of the CC-BY 4.0, which permits unrestricted use, distribution, and reproduction in any medium, provided the original author and source are credited. 


\section{INTRODUCTION}

$\mathrm{H}$ eritage constructions are a special group of structures with high artistic, cultural, religious, documental or aesthetics value for the society. They represent, in some way, the cultural identity of a community preserving its history over the time. Such constructions, playing an important role in the cultural heritage of many nations, are art works that contribute to the beauty of the built environment. In addition, attracting tourism, are an essential engine for the economic development of many cities and countries $[1,2,3,4]$.

As other types of buildings, heritage constructions are subjected to several scenarios of degradation and damage due to natural actions (thermal effects, chemical or physical attacks), anthropic actions and interventions (including alterations in the original building architecture) and also dynamic actions such as wind and earthquakes. For that, and considering its high cultural value, this special class of structures needs to be appropriately and periodically checked and maintained in order to assure structural safety conditions [5].

A large number of heritage constructions are located in seismic areas with different levels of seismic hazards, and there is a great interest from both the local administrations and the international organizations (UNESCO, ICOMOS, World Bank, etc.) to promote and support ad-hoc actions aimed to their preservation and maintenance. In this framework, based on the conservation of the World Heritage against earthquake loads, the scientific community plays a pivotal role, as also evidenced by the great number of researches published on this field in recent years [6, 7]. The study of the seismic behavior of masonry heritage constructions, shortly, is much debated than the one of new buildings because in case of historic constructions the occurrence of earthquakes, even if of small magnitude, may induce serious damages or even structural collapse. In general terms, the assessment of the seismic behavior of historic structures is very complex and depends on many factors such as the geometry of the structure, constructive typology, mechanical properties of materials, connections between the walls, etc. The mechanical propriety of masonry is one of the most challenging matters of the structural engineering because it is a heterogeneous, anisotropic and discontinues material due to the different types of components. For this reason, the reference values of the strength of the masonry material of the ancient constructions reported in literature or codes are always conservative. As highlighted by [8], the assessment of the seismic behavior of historic masonry structures is a challenging task also because the structural skeleton of a historic building is usually capable of safely resist to gravitational loads, but poorly perform against horizontal loads (like the earthquake ones).

According to [9] the study of the seismic vulnerability of historical constructions, that is, their susceptibility to damage under earthquake is very important because it allows to properly addressing the resources necessary to mitigate material and human losses. The seismic hazard is unavoidable; therefore actions aiming to minimize the impact of earthquakes on the structures should be directed to find solutions that improve the seismic performance of buildings.

In the seismic analysis, and assessment, of historical constructions many numerical methods can be used [7], the most of them are based on discretization techniques that use the Finite Element Method (FEM). With respect to the analysis methods, it is possible to recognize three main categories: (i) the modal analysis, usually based on linear models and combined with the concept of structural behavior factor $\mathrm{q}$ to account for the energy dissipation effects that occur in the structure during the earthquake ground motion, (ii) the nonlinear static analysis (pushover methods) and (iii) the nonlinear dynamic analysis $[10,11,12,13]$. The importance of a proper evaluation of the structural behavior of a heritage structure under seismic action - including proper method of analysis - is strictly connected with the historical and architectural value of these buildings and to the economic aspects of historic tourism in many countries $[14,15,16]$. Therefore is of high importance the need of analyzing the seismic response of a heritage structure in order to identify effective structural improvement strategies oriented to both the protection and the conservation of the architectural heritage.

In Brazil, the seismic hazard is considered low due to the country geographical position: Brazil is completely located on the South American Plate. However, recent history shows that earthquakes of high magnitudes have occurred in Brazil; for example: the Pacajús earthquake in the Ceará State, in 1980, of 5.2 mb magnitude [17]; the João Câmara earthquake in the Rio Grande do Norte State, in 1986, of $5.1 \mathrm{~m}$ bagnitude [18]; and also the most high earthquake ever registered in Brazil, the Porto dos Gauchos earthquake, in 1955, in the Mato Grosso State, of 6.2 mb magnitude [19].

In 2006 a technical norm of the Brazilian Association of Technical Standards (ABNT), "NBR 15421: Design of seismic resistant structures - Procedure" [20] was published and this norm currently classifies Brazil in 5 zones (from 0 to 4 ) according to their degree of seismicity. After the publication of this standard, the Brazilian research to evaluate the effects of earthquakes on structures has been growing, but in comparison to countries with high seismicity, such as Chile, Italy and Portugal, is still low. In the Brazilian scientific literature, still few are the case studies that analyze the potential effects of earthquakes on heritage constructions. This study aims to drive this growing field of research, discussing a representative case study in the city of Sobral. This city is located in the North region of Ceará State (Brazil), $230 \mathrm{~km}$ away from Fortale- 
za, the capital city, and, since 2008, an intense seismic activity has been observed in Sobral region where, according to [21], at $05 / 21 / 2008$ an earthquake of $4.2 \mathrm{~m}_{\mathrm{b}}$ magnitude was registered. The city of Sobral preserves a large number of heritage constructions in its historic center, which is one of the biggest and most important of Brazil with more than 1,200 buildings listed by the National Historic and Artistic Heritage Institute (IPHAN). Thus, aiming to contribute to preservation and safety of Sobral heritage constructions under seismic actions, this paper presents a seismic behavior assessment of a very important heritage construction from Sobral historic center, namely Nossa Senhora das Dores Church, a structure dating back the beginning of the $19^{\text {th }}$ century, built in solid bricks masonry and located near Acaraú River. In a first part of the paper, few remarks about the Brazilian seismicity and the geometric and constructive features of the Nossa Senhora das Dores Church are reported. Subsequently, the FE model of the church and the numerical linear time-history analyses performed employing two real earthquakes are discussed. The analyses were developed assuming the masonry mechanical behavior as a linear one; this means that the results herein described do not account for the cracking and the crushing phenomena that may be activated during the seismic event. A more refined analysis should be made taking into account the non-linear behavior of masonry, after a refined experimental investigation aimed at evaluating the material properties needed to implement the non-linear material laws $[22,23]$. The seismic analysis herein reported was hence aimed at a preliminary evaluation of the potential effects induced by seismic loading, assessing the structural elements that require a detailed and specific investigation.

\section{THE BRAZILIAN SEISMICITY: REGIONAL AND NORMATIVE ASPECTS}

A map of the South America seismic hazard, produced by United States Geological Survey (USGS), is shown in Fig. 1.(a): Peak Ground Accelerations (PGA) are reported both in $\mathrm{m} / \mathrm{s}^{2}$ and as a fraction of $g$ (the acceleration due to gravity) with a $10 \%$ probability of being exceeded in 50 years [24]. This figure shows that there is a large part of Brazil where there is not seismic activity or it is practically null (white area), however, in the northeast region of the country is possible to observe a small area seismically active, more precisely, the area between the states of Ceará, Rio Grande do Norte and Paraiba, that have considerable values of PGA, ranging between $0.02 \mathrm{~g}$ and $0.25 \mathrm{~g}$. Fig. 1 .(b) shows the Brazilian seismic catalog which, according to [19] indicates all the earthquakes already cataloged in the country from 1720 to 2016. The map includes ancient and recent earthquakes, and only superficial earthquakes are shown (i.e. depth $<50 \mathrm{~km}$ ). The blue circles are epicentres of historical earthquakes with magnitude estimated from the macrosimic effects. The red circles are epicentres of earthquakes recorded by seismographic stations. The empty circles - in the Andes - are epicentres of earthquakes in which the seismic waves have caused the oscillation of tall buildings in some Brazilian cities. Fig. 1 confirms that the northern part of the Ceará State, where the city of Sobral is located, has been affected by an intense seismic activity.
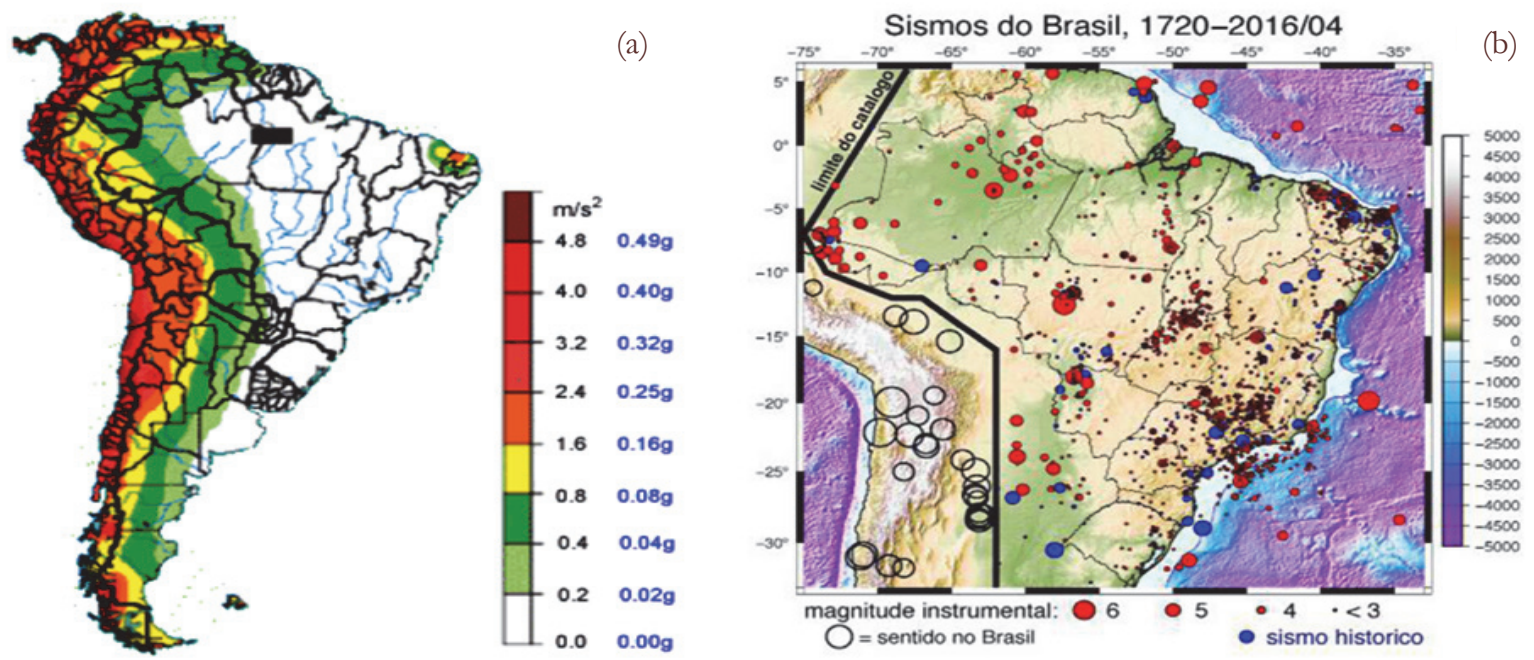

Figure 1: Brazilian seismicity: (a) map of the seismicity of South America [24] and (b) Brazilian Seismic Catalog [19].

As reported above, the city of Sobral is located in the north region of the Ceará State, and the Ceará State is located in the northeast region of Brazil. Sobral City is $230 \mathrm{~km}$ away from the capital city, Fortaleza. The Ceará State is located in a seis- 
mically active area, where in 1980 an earthquake of magnitude of $5.2 \mathrm{~m}_{\mathrm{b}}$ was registered in the Pacajús city. The seismic activity in the northeast region of Ceará State, more precisely, in the Sobral region, is very old and it is the second most important in the Brazilian northeast, being preceded only by the region of the edge of the Bacia Potiguar, that includes a large part of the State of Rio Grande do Norte and the eastern part of the Ceará State. Since 2008 an intense seismic activity in the Sobral region has been observed, where several earthquakes have occurred and the big of these was occurred on 05/21/2008, of $4.2 \mathrm{~m}_{\mathrm{b}}$ magnitude. The geographical position of the event and the seismogram recorded by the Riachuelo station (RCBR), located at Riachuelo-RN at approximately $572 \mathrm{~km}$ away from Sobral city, are shown in Fig. 2. These events have caused damage in some buildings.

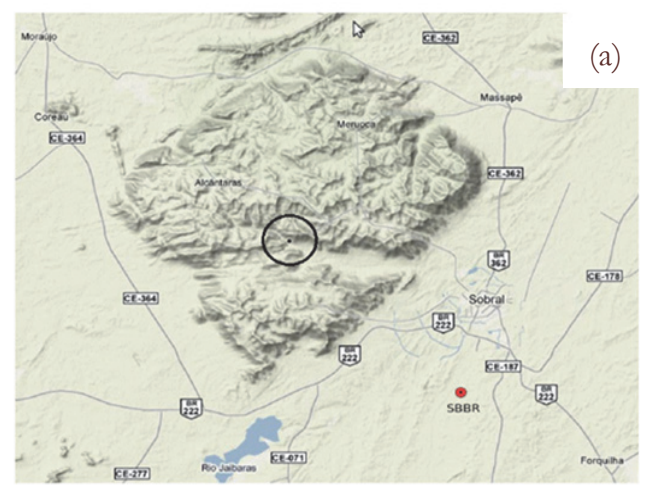

(a)

(b)

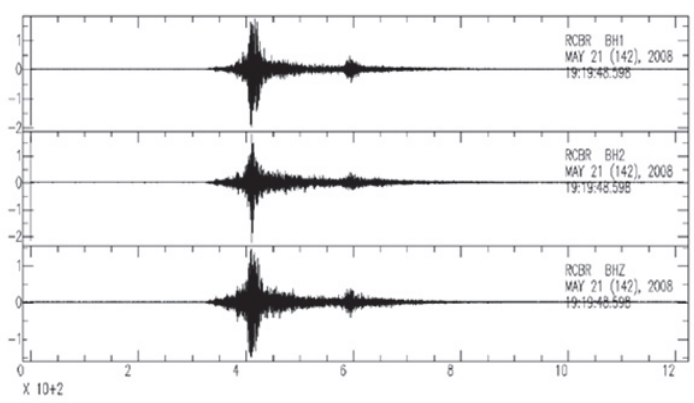

Figure 2: (a) geographical position of the earthquake of magnitude $4.2 \mathrm{mb}$ registered in 05/21/2008 (black circle) and (b) Seismogram of the event, where BH1 represents the component E-W, BH2 represents the component N-S and BHZ represents the vertical component (adapted from [25]).

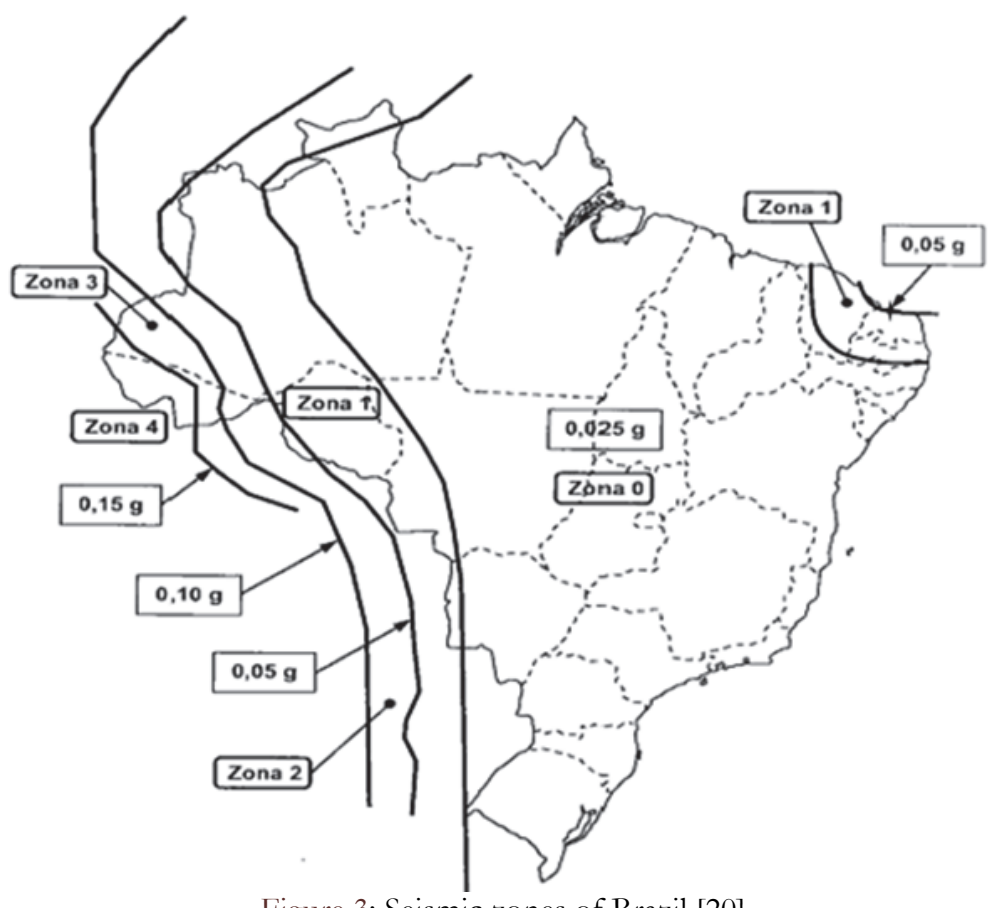

Figure 3: Seismic zones of Brazil [20].

Until 2005, the Brazil did not have a seismic code; only in 2006 the "NBR 15421: Design of seismic resistant structures Procedure" was published [20]. The current Brazilian norm requires that the structures on the Brazilian territory must be designed and built in order to withstand the effects of seismic loads. This standard defines the seismic loads, according to the Brazilian seismicity, and the methods of design and evaluation of the structures to be used. According to [26], for the elaboration of NBR 15421, a large study was developed in which a comparative analysis of the seismic technical standards of six South American countries was carried out observing their geographical continuity with Brazil. This allowed to de- 
fine the five Brazilian seismic zones presented in Fig. 3, with reference to the values of the ground accelerations for each zone as: Zone $0-\mathrm{a}_{\mathrm{g}}<0.025 \mathrm{~g}$; Zone $1-0.025 \mathrm{~g}<\mathrm{a}_{\mathrm{g}} \leq 0.05 \mathrm{~g}$; Zone $2-0.05 \mathrm{~g}<\mathrm{a}_{\mathrm{g}} \leq 0.10 \mathrm{~g}$; Zone $3-0.10 \mathrm{~g}<\mathrm{a}_{\mathrm{g}}<0.15 \mathrm{~g}$; and Zone $4-\mathrm{a}_{\mathrm{g}}>0.15 \mathrm{~g}$.

Analyzing the seismic zones shown in Fig. 3 , it is possible to observe that a large part of Brazil is covered by Zone 0 , that causes a maximum ground acceleration of $0.025 \mathrm{~g}$, that is, the soil moves at a maximum speed of about $0.245 \mathrm{~m} / \mathrm{s}^{2}$. However, in some North-Eastern states, such as Ceará, Rio Grande do Norte and Paraíba, most of their territories are located in Zone 1, that has the maximum ground acceleration of $0.05 \mathrm{~g}$ that corresponds to $0.490 \mathrm{~m} / \mathrm{s}^{2}$.

\section{The Nossa Senhora das Dores Church}

7 he Nossa Senhora das Dores Church (Fig. 4) is one of the most important historical buildings of the Sobral historic center, near the Acaraú River. Sobral is a city 345 years old, that keeps one of the largest and most important historic city centers of Brazil, with over around 1,200 properties registered by National Historic and Artistic Heritage Institute (IPHAN). This structure was chosen as case study being representative of the studies that should be performed on the Brazilian heritage constructions.

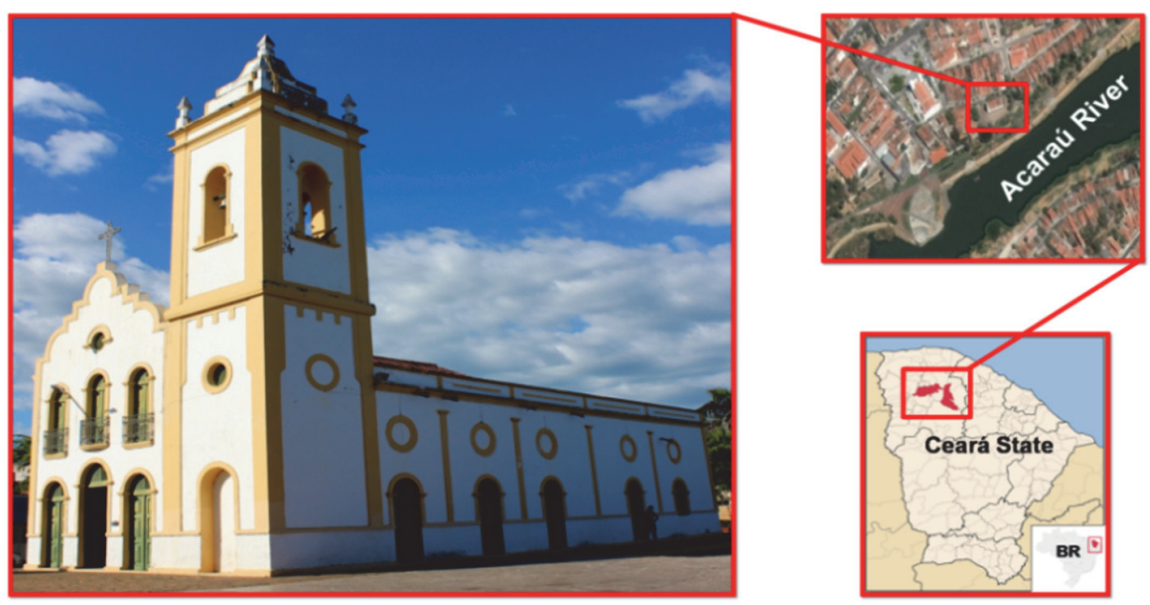

Figure 4: View of the Nossa Senhora das Dores Church with its location in Sobral City and location of Sobral city in Ceará State.

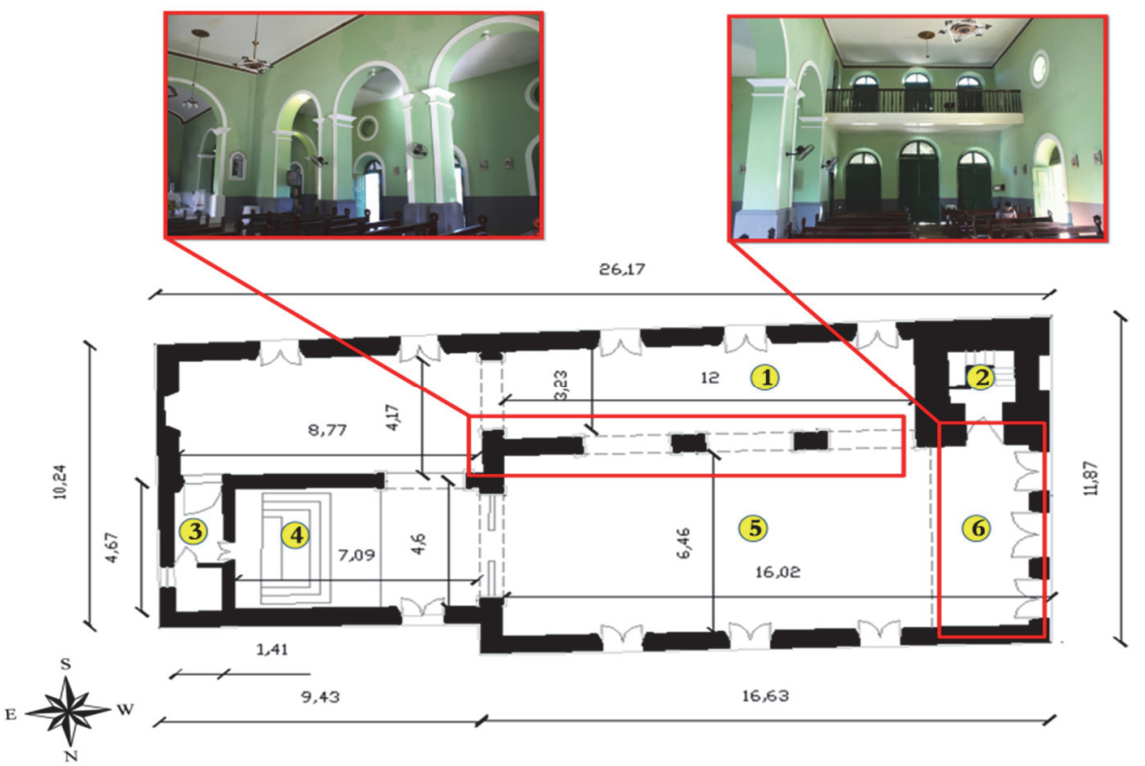

Figure 5: Schematic view of geometry of the Nossa Senhora das Dores Church, where (1) is the Lateral nave, (2) is the Lateral Tower, (3) is the office, (4) is the Altar-Mor, (5) is the Central Nave and (6) is the Coro-Alto. 
The church dates back from the beginning of the 19th century and was built in a place where there was a small niche in the old Rio street, near the Acaraú River [27]. This church is very close to the Igreja da Sé of Sobral, and next to the urbanization of the near left of the Acaraú River. Its structure is composed of clay bricks masonry, and the church was built using local constructive techniques. The church's geometry, shown in Fig. 5, is almost regular with a length of about $26.2 \mathrm{~m}$ and a width of about $11.9 \mathrm{~m}$; there is a lateral tower $20.50 \mathrm{~m}$ high. The structure is divided in a Central Nave (about $6.5 \mathrm{~m} \times$ $16.0 \mathrm{~m}$ ) and in a Lateral Nave (about $3.2 \mathrm{~m} \times 12.0 \mathrm{~m}$ ), separated by two columns and three arches. The Coro-Alto, the Altar-Mor and an office are located at the end of the building (Fig. 5).

\section{Finite element modeling}

Based on a geometric survey, provided by IPHAN-CE, and on the geometric characteristics observed by visual inspection, a 3D numerical model of the Nossa Senhora das Dores Church was built (Fig. 6). To build the 3D FE model some simplifications were done, aimed to reduce possible discontinuities in the finite element mesh. The architectural details of the main façade, the reinforced-concrete (RC) stair, the roofs and the Coro-Alto were not included in the model, but their respective loads and masses were applied on the corresponding walls.

The FE model was built with the commercial code ANSYS; SOLID187 tetrahedral elements with quadratic displacement behavior were employed (the finite element is defined by 10 nodes having three degrees of freedom at each node). A mesh-size of about $500 \mathrm{~mm}$ was adopted and the final FE model, shown in Fig. 6, was built with 53,889 elements and 93,380 nodes.

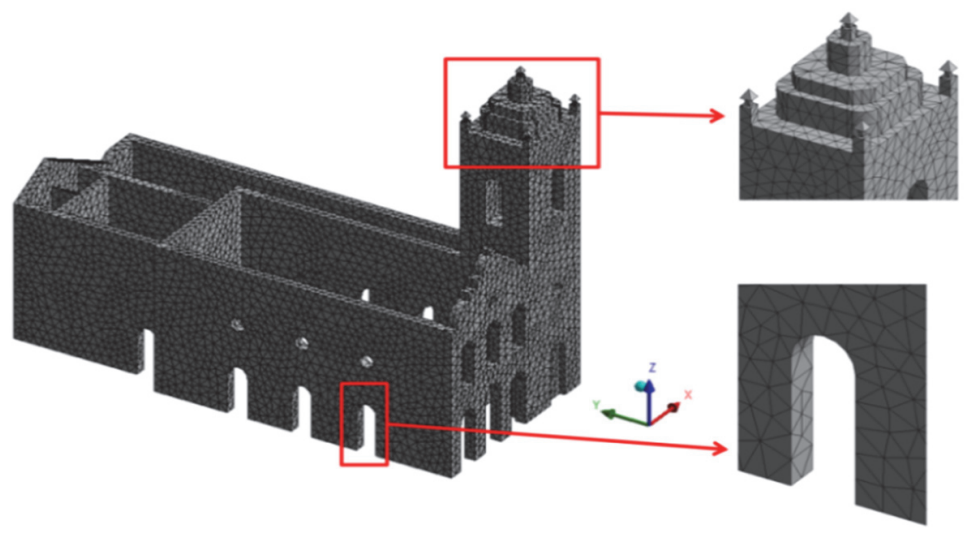

Figure 6: View of the 3D finite element numerical model of the Nossa Senhora das Dores Church.

With respect to the loads and weights of the structural elements, the following assumptions have been made. The stair loading was assumed, according to [28], equal to $2.50 \mathrm{kN} / \mathrm{m}^{2}$; this load was assumed uniformly distributed at the top surface of the four tower walls. To evaluate the Coro-Alto load, a timber type Pine was considered with specific weigh equal to $5.0 \mathrm{kN} / \mathrm{m}^{3}$. Taking into account the geometric dimensions of the Coro-Alto, its corresponding load is equal to 1.25 $\mathrm{kN} / \mathrm{m}^{2}$. The roof is a timber structure where the ceiling tiles are supported. At the intrados of the roof, a ceiling plaster as usually adopted in the Sobral region - is fixed at the timber structure. For the ceiling plaster a loading value of 0.60 $\mathrm{kN} / \mathrm{m}^{2}$ was adopted, the same adopted by [29]. For the roof load, a load of $1.30 \mathrm{kN} / \mathrm{m}^{2}$, the same adopted in [30], was used. This leads to a total load of $1.90 \mathrm{kN} / \mathrm{m}^{2}$. Considering an additional extra-load of $50 \%$ of the total load $(0.95$ $\mathrm{kN} / \mathrm{m}^{2}$ ), the total load of the roof was equal to $2.85 \mathrm{kN} / \mathrm{m}^{2}$. The roof load was distributed along of the walls that support the roofs element. The final applied loads in the numerical simulations are summarized in Tab. 1.

\begin{tabular}{ccccc}
\hline Stair $\left(\mathrm{kN} / \mathrm{m}^{2}\right)$ & Coro-Alto $\left(\mathrm{kN} / \mathrm{m}^{2}\right)$ & Roof $\left(\mathrm{kN} / \mathrm{m}^{2}\right)$ \\
2.50 & 1.25 & 2.85 & \\
\hline \multicolumn{4}{c}{ Table 1: Loads applied in the 3D numerical model } \\
\hline $\mathrm{E}(\mathrm{GPa})$ & $\mathrm{W}\left(\mathrm{kN} / \mathrm{m}^{3}\right)$ & $\mathrm{f}_{\mathrm{c}}(\mathrm{MPa})$ & $\mathrm{f}_{\mathrm{t}}(\mathrm{MPa})$ & $\nu$ \\
1.50 & 18.00 & 3.20 & 0.16 & 0.20 \\
\hline
\end{tabular}

Table 2: Preliminary mechanical properties of the numerical model 
The mechanical properties of the masonry are - obviously - key parameters, being the performance of the numerical model closely connected to their value. Concerning the estimation of the mechanical properties of the clay brick, the values reported in the literature due to the impossibility to proceed with experimental in situ characterization were preliminarily considered. The Young's modulus $(\mathrm{E})$, the specific weight $(\mathrm{W})$ and the compressive strength $\left(\mathrm{f}_{\mathrm{c}}\right)$ were obtained by the Italian recommendation "Norme Tecniche per le Costruqioni (NTC2008)" [31], taking into account as masonry type "Muratura in mattoni pieni e malta di calce" (full brick masonry with lime mortar). The tensile strength of the masonry ( $\mathrm{f}_{\mathrm{t}}$ ), was assumed as $5 \%$ of the compressive strength $\left(f_{c}\right)$. For the Poisson coefficient $(v)$, a value of 0.20 was considered, as commonly adopted in many studies $[29,32,33]$. Tab. 2 reports the mechanical properties of the clay brick masonry adopted in the numerical model.

\section{Calibration of the mechanical properties}

The numerical model of the Nossa Senhora das Dores Church was subsequently calibrated based on the experimental results obtained by performing environmental vibration tests (EVT). From the EVT, three testing positions were recorded and the Fourier Spectrum on the two principal directions of the Church was calculated. The obtained results are shown in Fig. 7.(a) for the X direction (the transversal one) and in Fig. 7.(b) for the Y direction (the longitudinal one). Analyzing the two spectra, it can be inferred that the first 3 natural frequencies of the church are included in the range between $2.00 \mathrm{~Hz}$ and $3.50 \mathrm{~Hz}$. Analyzing the frequencies with the highest amplitude with respect to each main direction of the church, the first fundamental frequency resulted $2.391 \mathrm{~Hz}$ in the $\mathrm{X}$ direction, the second was $2.880 \mathrm{~Hz}$ also in the $\mathrm{X}$ direction since the amplitude of the first two peaks in the $\mathrm{X}$ direction is greater than in $\mathrm{Y}$ direction. The third natural frequency was obtained in the Y direction, with the third peak of the spectrum in Fig. 7.(b), and was characterized as $3.125 \mathrm{~Hz}$ because in this direction its amplitude is greater than the third peak of spectrum in Fig. 7.(a).

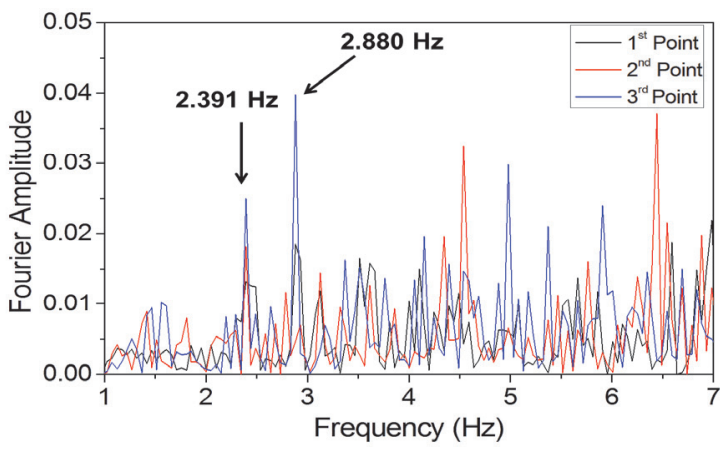

(a)

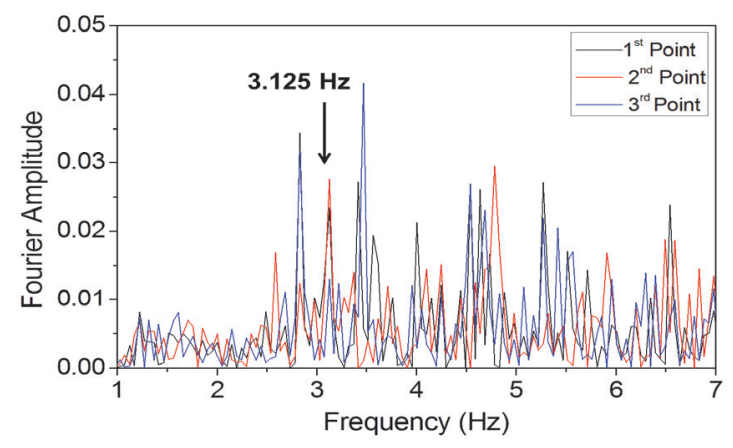

(b)

Figure 7: Fourier spectrum in (a) $\mathrm{X}$ direction and (b) in $\mathrm{Y}$ for the three points tested.

The elastic parameters of the FE model were hence calibrated in order to fit the natural frequencies obtained by the EVT, assuming as starting values the ones estimated in accordance with the Italian recommendation [31]. The specific weight and the masses have been keeping constant, and the Young's Modulus has been iteratively updated (within the range from $1.50 \mathrm{GPa}$ to $1.75 \mathrm{GPa}$ ) in order to fit the experimental values. The first three natural frequencies were assumed sufficient for the calibration. It is worth noting that, after calibrating the Young's Modulus in order to reproduce the first numerical natural frequency, a good adherence between experimental and numerical results was also obtained for the second and third frequency, denoting that the numerical model reproduces correctly stiffness and masses of the church. The final identified Young's Modulus was equal to $1.70 \mathrm{GPa}$. With this fitting, based only on the first frequency, the results and the errors associated with each frequency are shown in Tab. 3, while the first three numerical modal shapes are shown in Fig. 8.

\begin{tabular}{ccccc}
\hline Mode & Exp. Frequency $(\mathrm{Hz})$ & Ansys Frequency $(\mathrm{Hz})$ & Error $(\%)$ & Mode Type \\
1 & 2.391 & 2.403 & 0.502 & Transversal bending (X direction) \\
2 & 2.880 & 2.806 & 2.637 & Transversal bending (X and Y direction) \\
3 & 3.125 & 3.084 & 1.329 & Longitudinal bending (Y direction) \\
\hline
\end{tabular}

Table 3: Comparison between the experimental and numerical frequencies. 

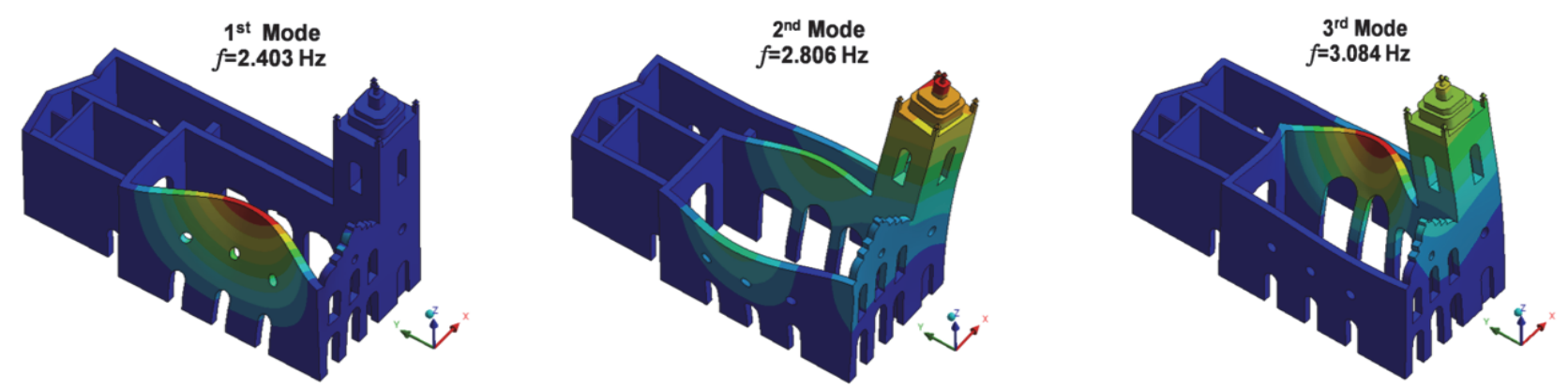

Figure 8: First three modal shapes of the Nossa Senhora das Dores Church.

In literature is rather usual the use of ambient vibration testing information for calibration of numerical models, summarizing the natural frequencies information about the modal parameters of the structure [34, 35, 36, 37, 38, 39]; usually, an error between experimental and numerical results up to about $5 \%$ is considered acceptable. In the present calibration the biggest error - obtained as the difference between the natural frequency of the structure extracted by ambient vibration test and the natural frequency extracted by numerical analysis - was $2.6 \%$, therefore the calibration has been considered successful (taking into account both the aim of the numerical model and its refinement). The elastic mechanical properties of the clay brick masonry after model updating are summarized in Tab. 4.

\begin{tabular}{ccccc}
\hline $\mathrm{E}(\mathrm{GPa})$ & $\mathrm{W}\left(\mathrm{kN} / \mathrm{m}^{3}\right)$ & $\mathrm{f}_{\mathrm{c}}(\mathrm{MPa})$ & $\mathrm{f}_{\mathrm{t}}(\mathrm{MPa})$ & $\nu$ \\
1.70 & 18.00 & 3.20 & 0.16 & 0.20 \\
\hline
\end{tabular}

Table 4: Mechanical properties adopted in the calibrated numerical model

Analyzing the numerical modal shapes of the church (Fig. 8), it is possible to observe that the first mode shape involves the translation in the weakest transversal direction ( $\mathrm{X}$ direction) of the wall of the North lateral façade, with significant out-of-plane deformation (out-of-plane mode of the longitudinal wall). The second and third modal shapes are still local modes, involving out-of-plane deformation of the façade, of the lateral walls and the central arches and the lateral tower. The distribution of the mode shapes demonstrates that the church displays low transversal and torsional stiffness, with significant out-of-plane deformations of the elements. This demonstrates that the dynamic response of the Church is strongly affected by the local behavior of elementary macro-elements. It is possible to observe that the participating masses of each mode of vibration are affected by high dispersion: the distribution of the first 100 vibration modes (in the longitudinal and transversal direction) is reported in Figure 9.(a).

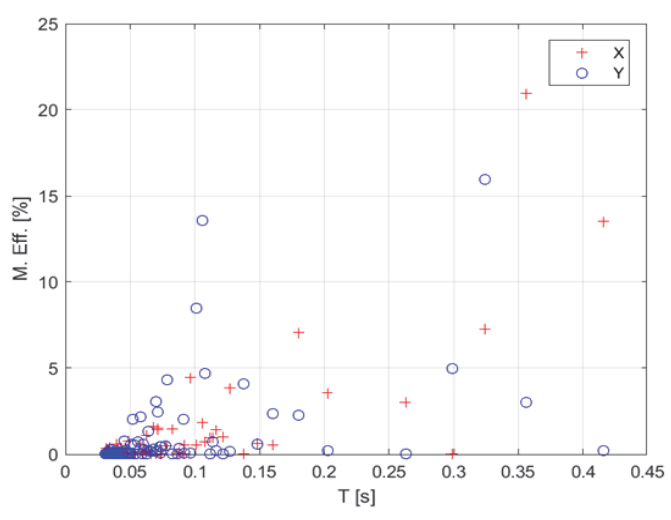

(a)

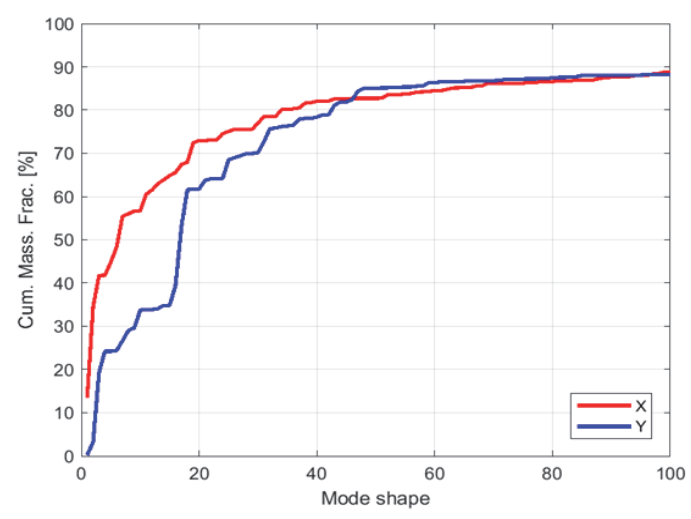

(b)

Figure 9: (a) Modal participating mass ratios vs. main periods and (b) cumulative modal mass ratio (CMF).

The modal participating mass ratios (ME) is plotted as a function of the corresponding period ( $\mathrm{T}$ ), and it is possible to observe that almost all vibration modes have modal participating mass ratio less than $10-15 \%$. As the participating mass ratio 
of each vibration mode is small, it is necessary to take into account about the first 100 modes to describe the dynamic behavior of the Church: the cumulative modal mass ratio is reported in Figure 9.(b).

In general, it is possible to observe that the first mode associated with not negligible participating mass is a transversal mode, namely the first out-of-plane mode of the longitudinal walls of the main nave. Dispersion of vibration modes for such typology of structures has been already observed by other authors [40, 41, 42] and this can be considered a specific structural characteristic of these structures, in contrast with ordinary or modern buildings where the modal participating mass is generally greater than $70 \%$ and the first three modes give a cumulative mass generally greater than $85 \%$. In addition, the results shown by the modal analyses are in agreement with the observation of the systematic analysis of the damage suffered by the churches after major earthquakes, that highlight that the church seismic behavior is predominantly ruled by the activation of local collapse mechanisms on several macro-elements [41, 43, 44, 45, 46]. As a consequence, only in the case of churches with symmetric plan layout and with effective connections between the various macro-elements, it could be significant to perform the safety checks with a pushover approach. The results of the modal analysis, in addition, show that no one of the first modes activates a relevant mass percentage, thus making doubtful the evaluation of the equivalent single-degree-of-freedom (SDOF) oscillator needed to perform the seismic check. Moreover, since the structure did not show a global box-behavior, it is not possible to identify a single control point representative of the whole model, which might uniquely define the structural capacity $[47,48]$. Taking into account these remarks, which substantially highlight the criticism of the pushover approach for such structural typology, linear time-history analyses have been herein performed to have a preliminary evaluation of the potential effects induced by seismic loading.

\section{Static analysis}

The identified numerical model has been preliminarily employed to perform a static analysis under dead and live loads. The stress maps are shown in Fig. 10, where both the maximum principal stress (Figs. 10.(a) and 10.(b)) and the vertical stresses (Figs. 10.(c) and 10.(d)) are reported. The maximum tensile stress is about $0.14 \mathrm{MPa}$ and was found in many regions of the structure such as: in the center of the arch facing the altar; in the openings of the Lateral Façade west; in the openings of the Lateral Tower and the connection between the central arches and the Lateral Tower. This value is lower than the maximum admissible value assumed for the tensile strength $(0.16 \mathrm{MPa})$.

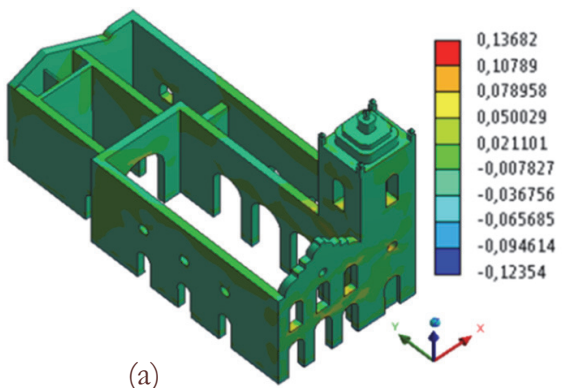

(a)

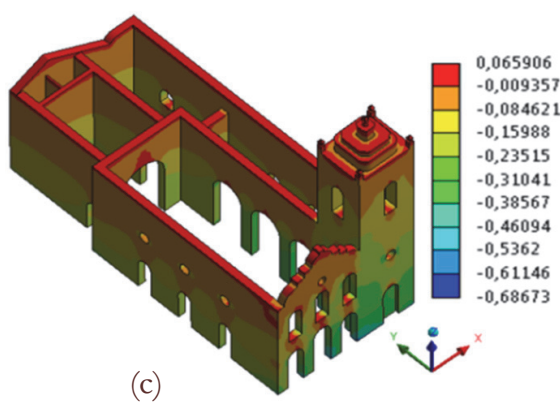

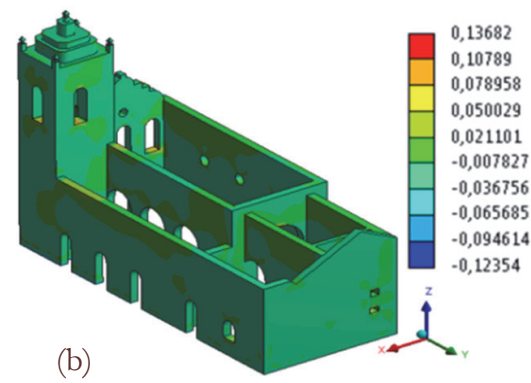

(b)

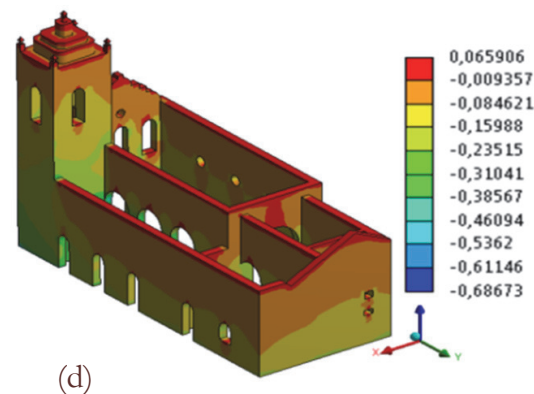

(d)

Figure 10: Results from the static analysis of the Nossa Senhora das Dores Church: (a) and (b) maximum principal; (c) and (d) vertical stress. Unit in $\mathrm{MPa}$.

Positive values of normal stress can be mainly identified in the surrounding opened regions, like the arches in the doors and the windows. In the main façades, positive values of normal stress indicated the existence of tensile stresses especially between the top of the arches of the doors and the bottom of the windows, while negative values of normal stress are related to compression. However, 0.69 $\mathrm{MPa}$ was the maximum value of the compressive stress, while the maximum value of 
the tensile stress was identified as $0.065 \mathrm{MPa}$. These values are less than load capacity of the clay brick masonry, here estimated as 3.20 MPa (compressive strength) and $0.16 \mathrm{MPa}$ (tensile strength).

\section{Seismic analysis}

To analyze the seismic behavior of the church, linear time-history analyses of the structure were performed. Due to the absence of natural records of Brazilian earthquakes, records of real earthquakes occurred in other countries were used. The church was subjected to two earthquakes of different magnitudes with time-length of $30 \mathrm{~s}$ each one. As Earthquake 1 , obtained by [49], the three components of the accelerogram of the San Juan de los Llanos earthquake (Fig. 11) occurred on 06/15/2014, $36 \mathrm{~km}$ from Ometepec, Guerrero, Mexico, of magnitude 4.1 with peak ground acceleration of $0.048 \mathrm{~g}$ on the component N00W was used. This earthquake was selected because its peak ground acceleration is very close to the value of the soil acceleration of the Sobral city which, according to the seismic zoning of [20], is located in Zone 1 with a maximum acceleration of $0.05 \mathrm{~g}$. In addition, the magnitude of this earthquake is consistent with the seismic hazard of Sobral city, because the biggest earthquake recorded in this region had a magnitude of $4.2 \mathrm{~m}_{\mathrm{b}}$.
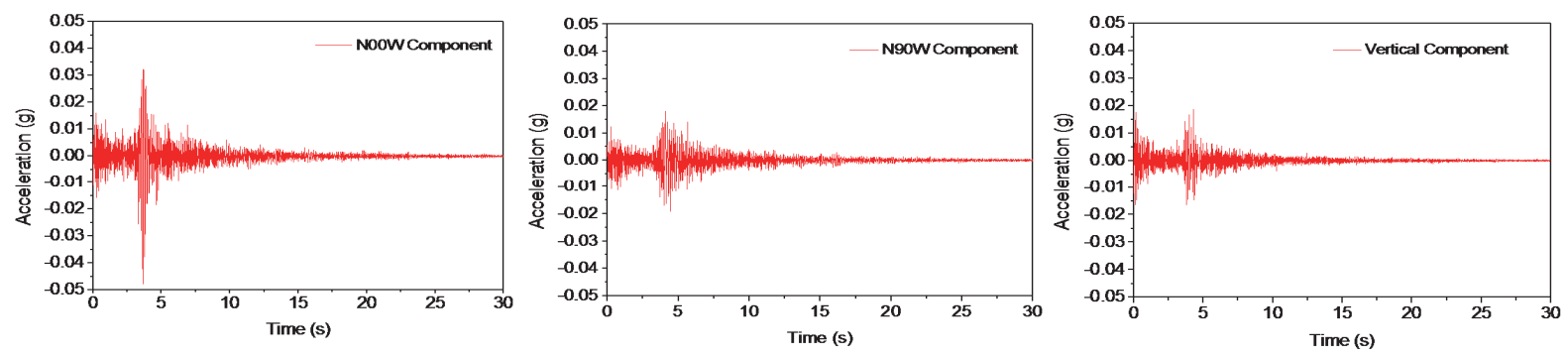

Figure 11: Accelerograms of the Earthquake 1- San Juan de los Llanos.

As Earthquake 2, the three components of the El Centro earthquake (Fig. 12; [50]), registered in El Centro, California, USA, at 05/18/1940, with a magnitude of $6.9 \mathrm{M}_{\mathrm{w}}$ and peak ground acceleration of $0.348 \mathrm{~g}$ on the S00E component was adopted. It was used because it is one of the most emblematic earthquakes, and also because in Brazil an earthquake of similar magnitude, according to [19], was occurred at 1955 in Porto dos Gauchos, State of Mato Grosso and had 6.2 mb.
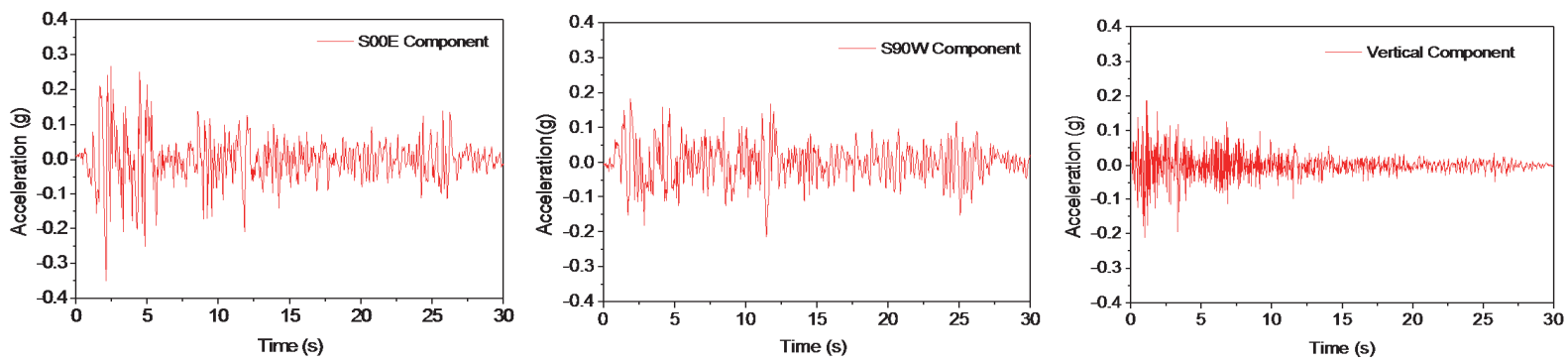

Figure 12: Accelerograms of the Earthquake 2- El Centro.
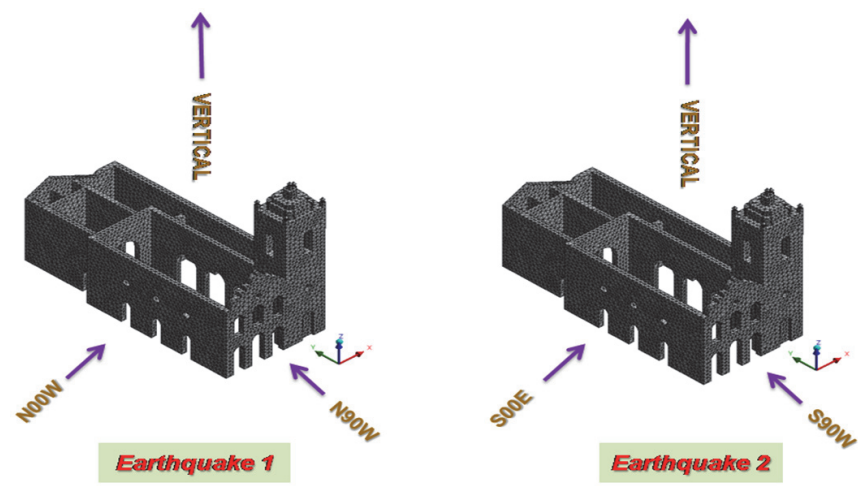

Figure 13: Applying of the three accelerograms of each earthquake on the 3D numerical model. 
The three accelerograms of each earthquake were applied at the base of the FE model through the transient analysis by modal superposition in ANSYS. The three accelerograms were simultaneously and orthogonally applied in the three axes of the numerical model, as shown in Fig. 12. For each analysis, an integration interval of $0.02 \mathrm{~s}$ and with $30 \mathrm{~s}$ length was adopted, thus, the total of points of integration was 1,500 .

\section{RESULTS AND DISCUSSIONS}

\section{Earthquake 1- San Juan de los Llanos}

T n Fig. 14 the displacements that occurred in the structure over the three axes $(\mathrm{X}, \mathrm{Y}$ and $\mathrm{Z})$ after Earthquake 1 are shown. Figs. 14.(a) and 14.(b) show the displacements in the $\mathrm{X}$ direction. In this direction the biggest displacement, about $0.5 \mathrm{~mm}$, is observed in three regions, namely: i) the wall of the north lateral façade; ii) part of the region of the central arches that separate the two naves and iii) at the top of the lateral tower. However, the biggest displacement in the $\mathrm{X}$ direction is found over the negative $\mathrm{X}$ direction and was recorded in a region of the wall of the south lateral façade (with a value of about $0.98 \mathrm{~mm}$ ). The displacements along the $\mathrm{Y}$ direction are shown in Fig. 14.(c) and 14.(d). The maximum, in the positive direction, about $0.18 \mathrm{~mm}$, is recorded in: i) the center of the wall of the west main façade, ii) the top of the wall of east façade and iii) the top of the main arch that is located in front of the altar-Mor. The biggest displacement over the negative $\mathrm{Y}$ direction, about $0.79 \mathrm{~mm}$, was observed at the top of the west main façade. The vertical displacements are represented in Figs. 14.(e) and 14.(f). Vertical displacements are very low; the maximum displacement is $0.08 \mathrm{~mm}$ and occurs in the rear diagonal of the lateral tower. The biggest displacement over the negative $\mathrm{Z}$ direction is observed at the diagonal of the lateral tower along of the west main façade and its value is equal to $0.10 \mathrm{~mm}$.

(a)
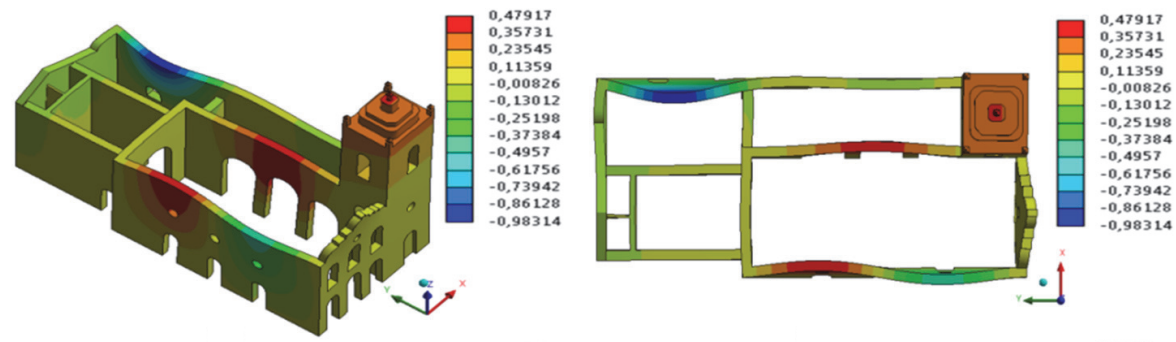

(c)
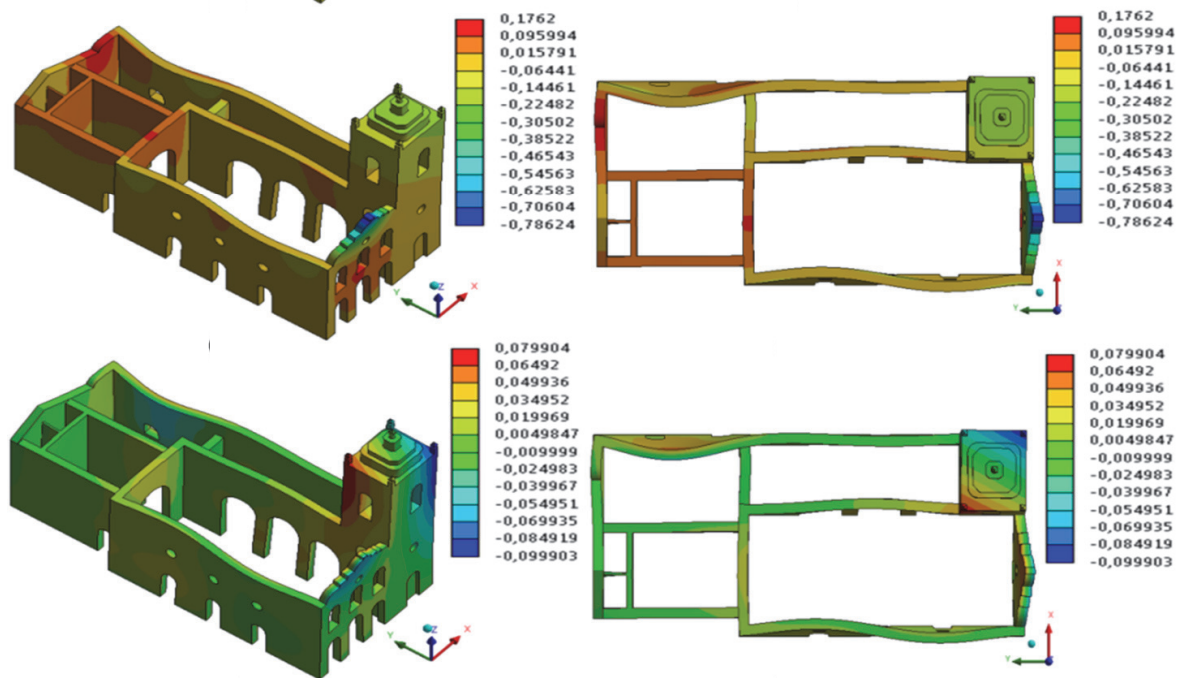

(b)

Figure 14: Directional displacements after Earthquake 1: (a) and (b) in direction X; (c) and (d) in direction Y; (e) and (f) in direction Z. Unit in $\mathrm{mm}$.

The maximum and minimum principal stresses are reported in Fig. 15. Analyzing Fig. 15.(a) and 15.(b), it can be observed that the maximum tensile stress is located in correspondence of the connection between the west main façade and the north lateral façade (about 0.15 MPa). This traction is due to the displacement of the west main façade out of the XZ plane. In some interior regions of the wall of the south lateral façade, tensile stresses of approximately $0.08 \mathrm{MPa}$ are also 
found. In the walls of the north lateral façade and the wall of the east façade it can be observed traction zones of 0.07 $\mathrm{MPa}$. The minimum principal stresses (negative values indicates as usual compression stress) are represented in Fig. 15.(c) and 15. (d). Values of about $0.11 \mathrm{MPa}$ can be identified in correspondence of the connection of the wall of the south lateral façade with the wall of a smaller arc located in the rear of the lateral nave. This value is lower than the one obtained with the static analysis (whose value was about 0.69 MPa). These compressive stresses are lower than the assumed compressive strength of the clay brick. However, in other regions of the structure compression stresses were observed, namely: i) the wall of the main west façade and the wall of the north lateral façade, approximately $0.06 \mathrm{MPa}$; ii) some regions of the wall of north lateral façade, where the stress is between $0.10 \mathrm{MPa}$ to $0.03 \mathrm{MPa}$.

(a)

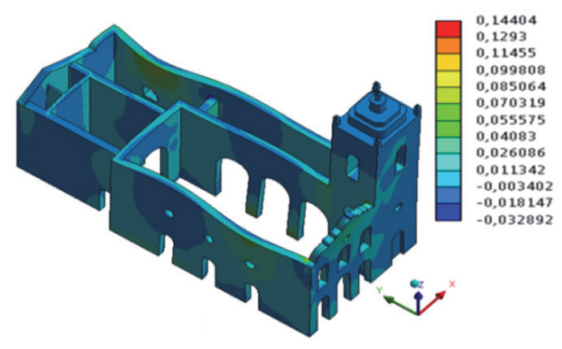

(c)

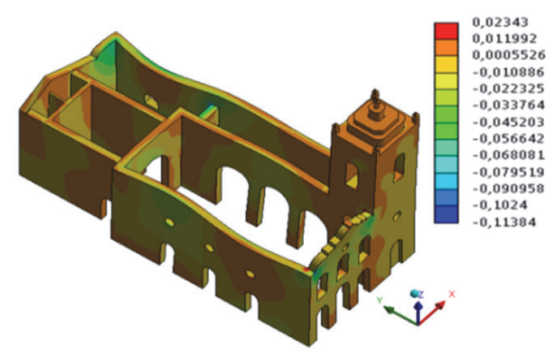

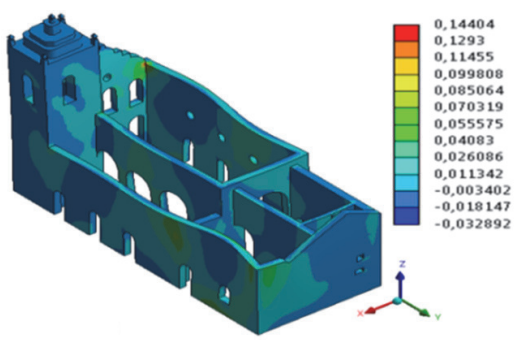

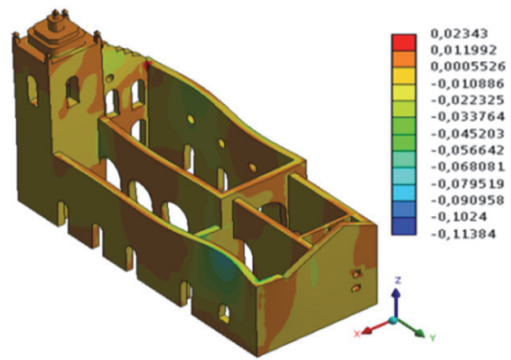

(b)

Figure 15: Principal stress after Earthquake 1: (a) and (b) maximum principal stress; (c) and (d) minimum principal stress. Unit in MPa.

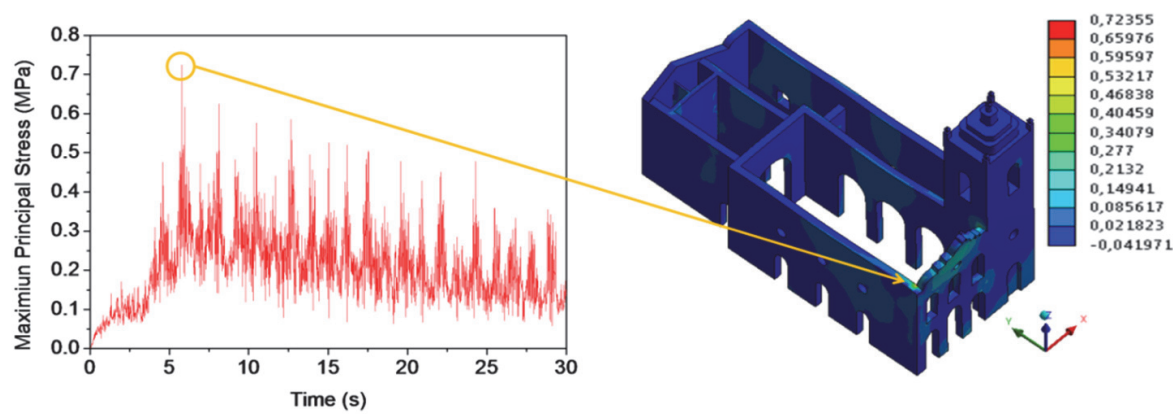

Figure 16: Peak of the maximum principal stress during Earthquake 1. Unit in MPa.

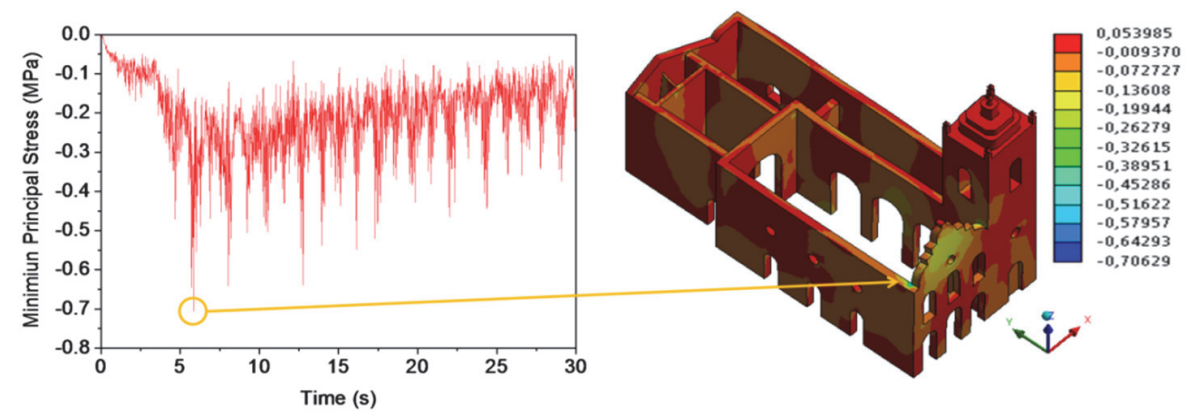

Figure 17: Peak of minimum principal stress during Earthquake 1. Unit in MPa. 
A peak of tensile stress (Fig. 16) equal to $0.72 \mathrm{MPa}$ at $\mathrm{t}=5.78 \mathrm{~s}$ was observed in correspondence of the connection between the wall of the north lateral façade with the wall of the west main façade. The peak of tensile stress is due to the motion of the upper part of the wall of the west main façade out of the $\mathrm{XZ}$ plane. This value is higher than the assumed tensile strength, and it highlights a vulnerability of the pediment of the church (its overturning).

Concerning the minimum principal stress, a peak of compression (Fig. 17) was also observed. In this case, this peak was evidenced at $\mathrm{t}=5.92 \mathrm{~s}$ and had a value of $0.71 \mathrm{MPa}$. A similar value was also found in the connection between the wall of the north lateral façade with the wall of the west main façade. This value is lower than the assumed compression strength (3.20 MPa), but is interesting since it confirms a vulnerability of the church: the overturning of the main façade during the Earthquake 1.

Both the maximum principal stress peak $(0.72 \mathrm{MPa}$ at $\mathrm{t}=5.78 \mathrm{~s})$ and the minimum principal stress peak $(0.71 \mathrm{MPa}$ at $\mathrm{t}=$ $5.92 \mathrm{~s}$ ) were obtained after the peak ground acceleration of the Earthquake 1 accelerogram (the N00W component was $0.048 \mathrm{~g}$ at $\mathrm{t}=3.64 \mathrm{~s}$, the N90W component was $0.019 \mathrm{~g}$ at $\mathrm{t}=4.45 \mathrm{~s}$ and the Vertical component was $0.018 \mathrm{~g}$ at $\mathrm{t}=4.31 \mathrm{~s}$ ).

\section{Earthquake 2- El Centro}

The displacements obtained using the Earthquake 2 are shown in Fig. 18; the maximum displacements in the X direction, Figs. 18.(a) and 18.(b), are about $4.30 \mathrm{~mm}$ and are located at the top of the central region of the wall of the south lateral façade (and also in correspondence of the wall of the central arches that separates the two naves). The biggest displacement, however, occurs in the wall of the north lateral façade along the negative $\mathrm{X}$ direction and has a value of about 15. $90 \mathrm{~mm}$. The displacements in the Y direction are shown in Fig. 18.(c) and 18.(d). It can be observed that the biggest value along the positive $\mathrm{Y}$ direction (the longitudinal one) is equal to $1.10 \mathrm{~mm}$ and is recorded on the wall of the north lateral façade and on the wall of the west main façade. The biggest displacement occurs in the negative Y direction, is located at the top of the lateral tower and corresponding to about $12.10 \mathrm{~mm}$. In the region of the central arcs, displacements of approximately $2.2 \mathrm{~mm}$ in negative $\mathrm{Y}$ direction are also evidenced.

(a)
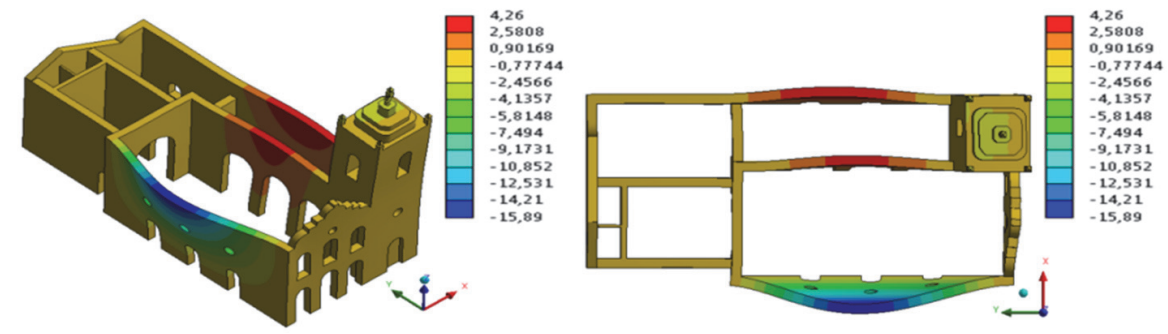

(c)
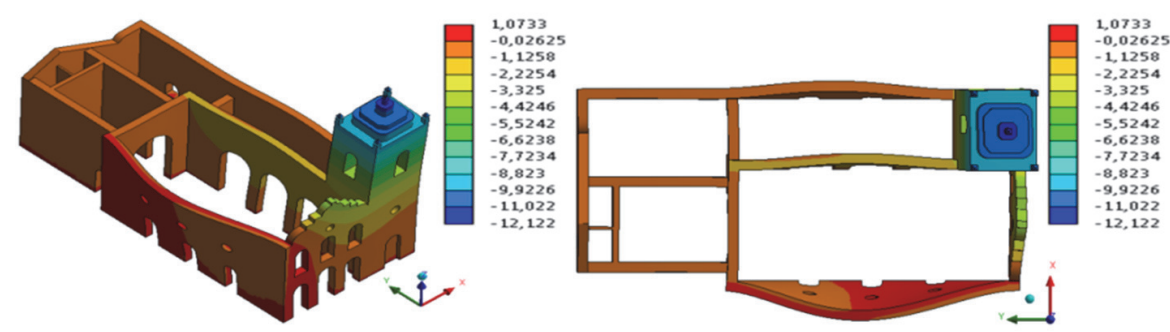

(e)

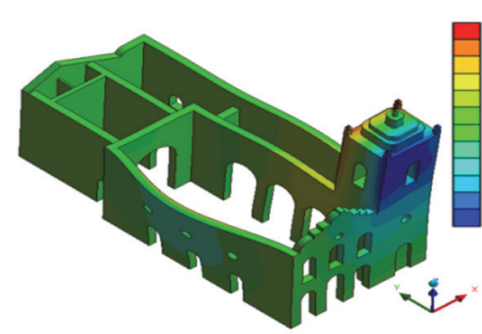

(b)

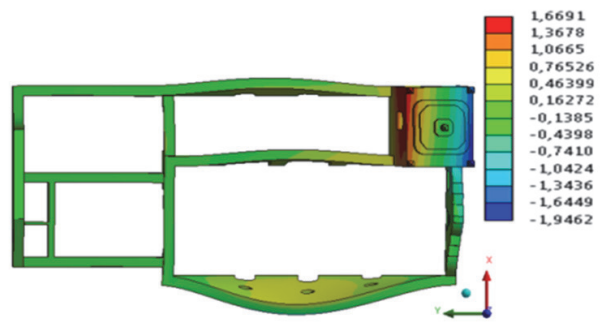

(d)

(f)

Figure 18: Directional displacements after Earthquake 2: (a) and (b) direction X; (c) and (d) direction Y; (e) and (f) direction Z. Unit in $\mathrm{mm}$. 
With respect to the vertical displacements, represented in Fig. 18.(e) and 18.(f), the back side of the lateral tower near the top, presents displacements of about $1.70 \mathrm{~mm}$ in the positive $Z$ direction. The front side of the lateral tower also presents displacement of $1.95 \mathrm{~mm}$, in module, along the negative $Z$ direction. In addition, the wall of the region of the central arches connected to the side tower exhibits displacement of approximately $1.10 \mathrm{~mm}$ in the positive $\mathrm{Z}$ direction. As a general comment, analyzing the displacements exhibited by the church during the earthquake, it is possible to observe the absence of a box-behavior: the church behaves as a combination of independent macro-elements with first and second mode potential failures.

The principal stresses are shown in Fig. 19. The maximum tensile stress, reported in Fig. 19.(a) and 19.(b), reached the value of $1.37 \mathrm{MPa}$, in correspondence of the connections of the lateral tower with the wall of the south lateral façade and the wall of the central arches. A similar value was found in correspondence of the connection of the wall of the north lateral façade with the wall of the main façade. These values are higher than the assumed tensile strength and denote potential collapse (and/or possible pounding) of this connection. A region of the wall of the north lateral façade with traction of about $0.74 \mathrm{MPa}$ is also observed. The walls of the central arches and the wall of the south lateral façade reached a tensile stress of about $0.244 \mathrm{MPa}$, that indicate potential cracks. The minimum principal stresses (compressive stress) are reported in Fig. 19.(c) and 19.(d). The higher value of about $0.65 \mathrm{MPa}$, occurs in many regions of the structure, namely: i) in the upper left corner of the west main façade, just above of the door opening; ii) in the first arc in contact to the lateral tower; iii) in the inferior central region, situated at the base of the door aperture and iv) in the upper left corner of the north lateral façade. In the front side of the lateral tower, the same west main façade, compressive stress ranging from $0.03 \mathrm{MPa}$ to $0.51 \mathrm{MPa}$ were observed.

(a)
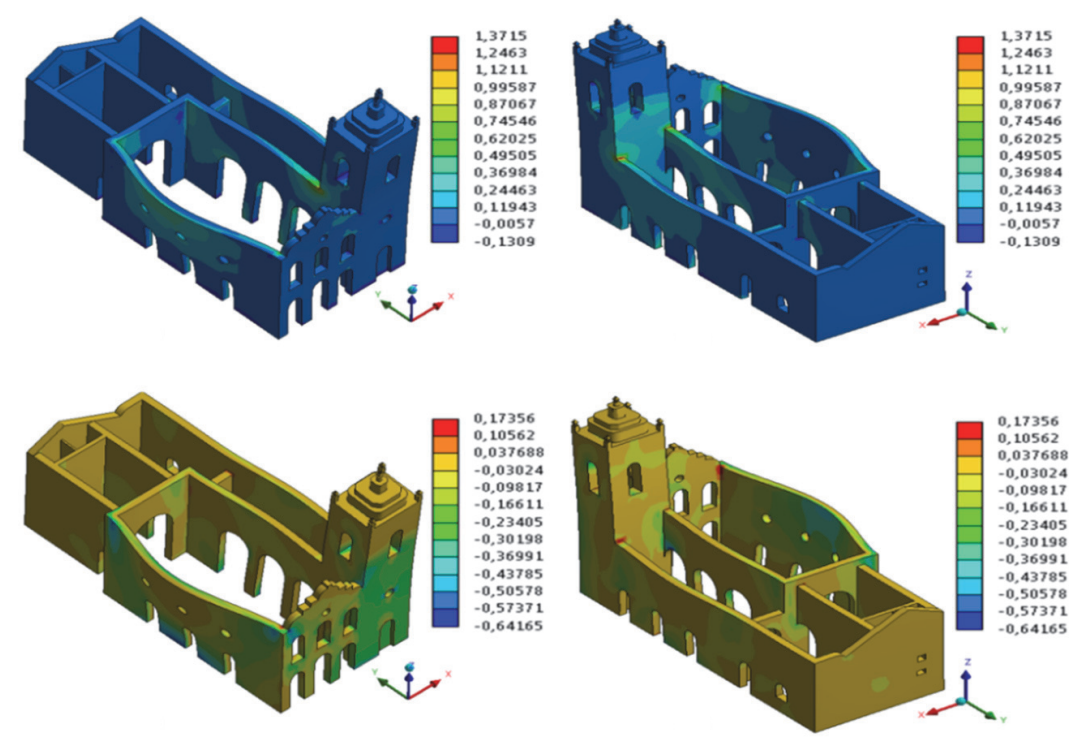

(b)

Figure 19: Principal stress after Earthquake 2: (a) and (b) maximum principal stress; (c) and (d) minimum principal stress. Unit in MPa.

During the Earthquake 2, a maximum principal stress peak was observed as reported in Fig. 20. The peak is a tensile stress of about $5.54 \mathrm{MPa}$ at $\mathrm{t}=10.34 \mathrm{~s}$ and is obtained at the base section of a column of the central wall of the structure. The high value denotes a potential collapse the column due to overturning. Other critical zones can be identified, namely: i) the region of connection of the wall of the central arches with the wall of the triumphal arch in front of the altar (which is subjected to a tensile stress of about $2.19 \mathrm{MPa}$ ); ii) the region of connection of the wall of central arches with the lateral tower, just above the first arch (with a peak of tensile stress of about $3.30 \mathrm{MPa}$ ); iii) the region of connection of the wall of the west main façade with the lateral tower (with a tensile stress of about $1.64 \mathrm{MPa}$ ); iv) the upper region of the central arches and the inferior region of the smaller arc, located at the end of the smaller nave (about 2.19 $\mathrm{MPa}$ and $3.30 \mathrm{MPa}$, respectively). In all these regions cracks and/or local collapses are potentially expected during the seismic loading.

The time-history of the minimum principal stress is reported in Fig. 21. It is possible to observe a peak of stress of about $5.66 \mathrm{MPa}$ at $\mathrm{t}=10.66 \mathrm{~s}$ at the base of the column of the central arch. This region is the same that presented a peak of traction (see Fig. 20), and this result is a confirmation of the potential overturning of this central wall during the earthquake. Other regions present high compressive stresses, namely: i) the upper part of the first arc in contact with the lateral tower (a compression of about $3.94 \mathrm{MPa}$ is recorded); ii) the region of connection between the upper part of the wall of the central arches with the wall of the arch in front of the altar and iii) the internal wall of the south lateral façade in 
contact with the smaller arch located at the end of the smaller nave (for all these regions, the compressive stresses are about $3.37 \mathrm{MPa}$ ). The analysis of the stresses confirms the tendency of the church, over the whole time-history, to behave as a combination of macro-elements that are activated after the potential collapse of the connection between the walls.

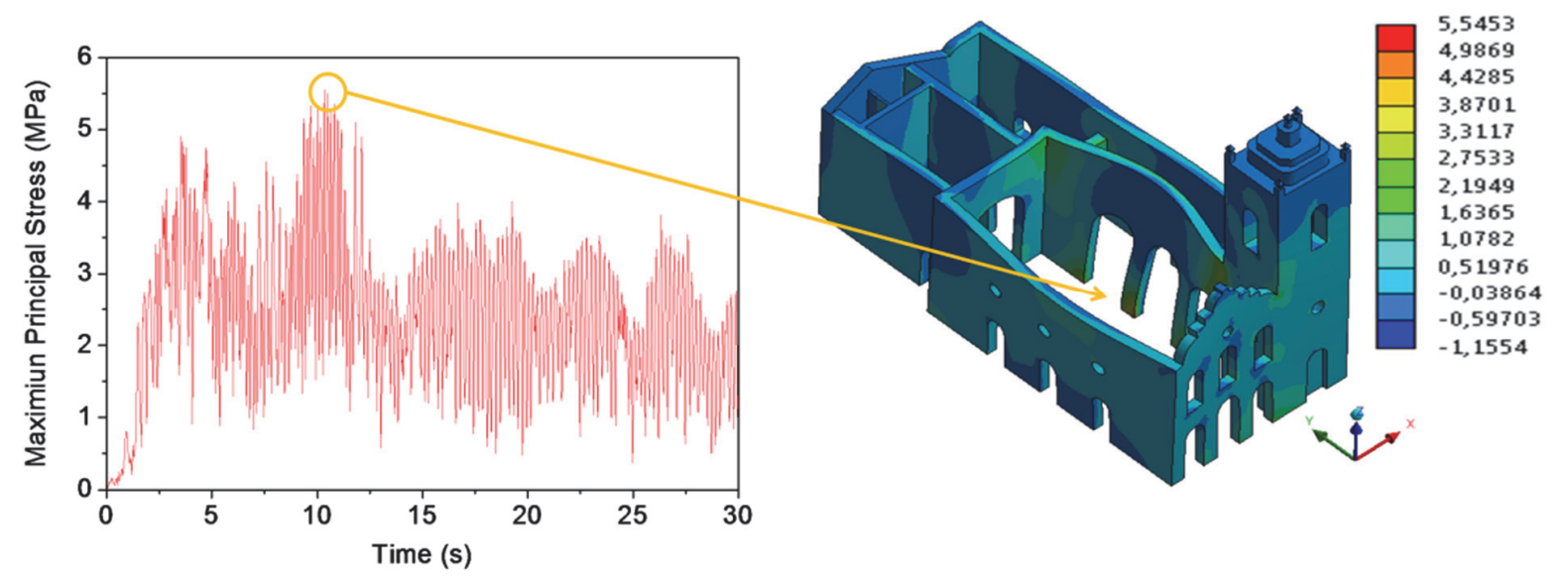

Figure 20: Peak of maximum principal stress during the Earthquake 2. Unit in MPa.

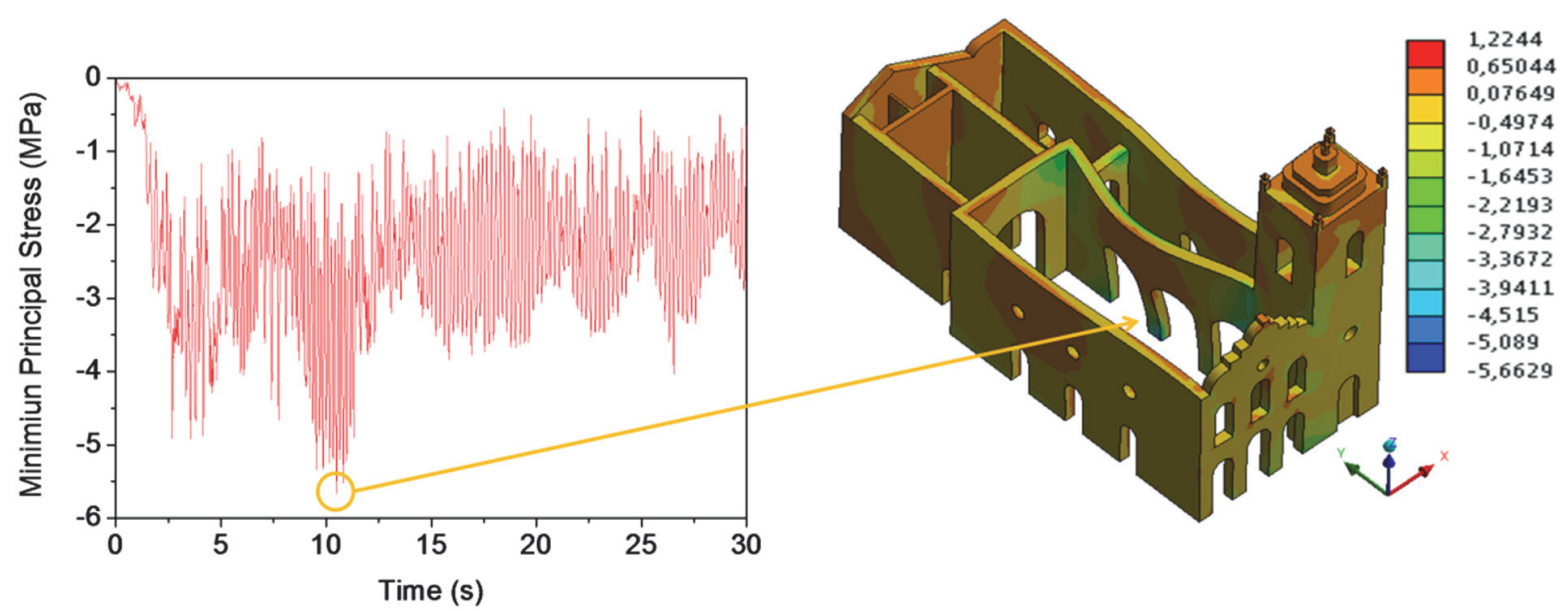

Figure 21: Peak of minimum principal stress during the Earthquake 2. Unit in MPa.

Both the maximum principal stress peak (5.54 MPa at $\mathrm{t}=10.34 \mathrm{~s})$ and the minimum principal stress peak $(5.67 \mathrm{MPa}$ at $\mathrm{t}=$ $10.66 \mathrm{~s}$ ) over the structure were not close to the peak ground acceleration of the Earthquake 2 accelerograms (the S00E component was $0.348 \mathrm{~g}$ at $\mathrm{t}=2.12 \mathrm{~s}$, the Vertical component was $0.21 \mathrm{~g}$ at $\mathrm{t}=0.98 \mathrm{~s}$; however the S90W component was $0.214 \mathrm{~g}$ at $\mathrm{t}=11.44 \mathrm{~s})$.

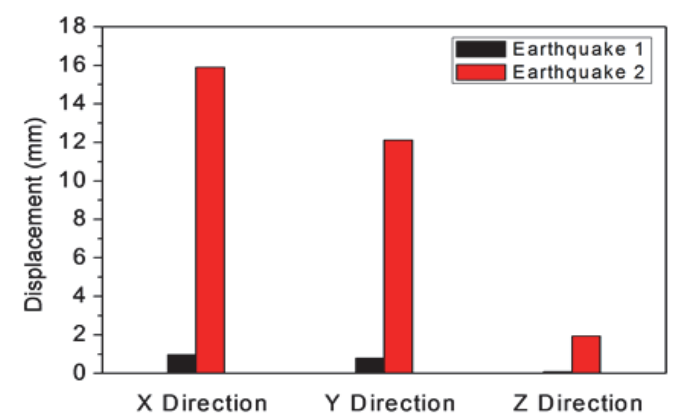

(a)

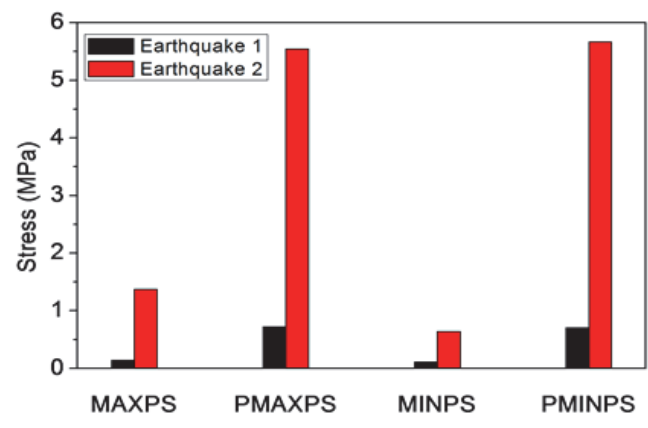

(b)

Figure 22: Comparison between (a) the directional displacements and (b) the principal stresses obtained in the seismic analyzes. 
Comparison between the results obtained by Earthquake 1 and Earthquake 2

During the application of Earthquake 1 and Earthquake 2 to the Nossa Senhora das Dores Chruch, directional displacements in the $\mathrm{X}, \mathrm{Y}$ and $\mathrm{Z}$ directions and principal stresses are obtained, as well as the peaks of stress during the $30 \mathrm{~s}$ of seismic loading. Because the two earthquakes have different magnitude, different frequency content, different peak ground acceleration and because the peaks are also different between the three components of each earthquake, the results obtained in the two analyzes show significant differences. In Fig. 22.(a) the maximum value of the directional displacements obtained in the two analyzes is reported while Fig. 22.(b) reports and compares the maximum and minimum principal stresses obtained during the two time-histories. The Earthquake 2, as expected, was the one that caused greater displacements and higher stresses. It can be interesting, anyway, to observe that in both cases the biggest displacements over the time-histories are obtained in the $\mathrm{X}$ direction (the transversal one), thus confirming the potential overturning of the main nave of the church.

\section{CONCLUSIONS}

$\mathrm{T}$

he paper investigated the seismic behavior of Nossa Senhora das Dores Church, an important heritage construction within the historic city center of Sobral (Ceará State, Brazil). The work aims to contribute to the acquisition of knowledge about seismic the behavior of Brazilian heritage constructions. First, based on the available information, a refined 3D numerical model of the church was build. The elastic properties of the model, after a preliminary estimation, were calibrated according to the results of an experimental investigation (environmental vibration testing aimed to evaluate the main frequency of the structure). Subsequently, the seismic behavior of this structure was assessed by performing linear time-history analyses according to two seismic scenarios: two natural records were considered. The response of the church under the two seismic events was analyzed in the linear field, this means that the obtained results do not account for the cracking and the crushing phenomena that may be activated during the seismic loadings. Consequently, a more refined non-linear time-history analysis should be performed after a refined experimental investigation aimed at evaluating the properties of the materials needed to implement the non-linear material laws. Notwithstanding, the preliminary results herein reported are able to highlight - even if from a qualitative point of view- the most significant elements that characterize the behavior of the structure during the earthquake identifying potential seismic vulnerabilities and deficiencies. By the analysis of the results of the time-histories, it was found, for example, that the church behaves as a combination of independent macro-elements (i.e. without a box-behavior) with first and second mode potential failures. Depending on the earthquake (its magnitude, its PGA and its frequency content), the overturning of the main facade, of the lateral and central walls and pounding between the lateral tower and the confining walls is expected. This suggests possible retrofitting solutions that can be proposed to improve seismic performance, structural safety and construction preservation.

\section{ACKNOWLEDGMENTS}

7 he authors would like to acknowledge the National Historic and Artistic Heritage Institute (IPHAN), the Paróquia de Nossa Senhora da Conceição in Sobral and the Laboratório de Reabilitação e Durabilidade das Construções (LAREB) for all support and useful information for development of this work. Francisco Brandão acknowledges the State University of Vale do Acaraú by research fellowship.

\section{REFERENCES}

[1] Roca, P., Cervera, M., Gariup, G. and Pelà, L. (2010). Structural Analysis of Masonry Historical Constructions. Classical and Advanced Approaches. Archives of Computational Methods in Engineering, 17(3), pp. 299-325. DOI: 10.1007/s11831-010-9046-1.

[2] Fioravanti, M. and Mecca, S. (2011). The safeguard of cultural heritage: A challenge from the past for the Europe of tomorrow. Florence: Firenze University Press.

[3] Bowitz, E. and Ibenholt, K. (2009). Economic impacts of cultural heritage - research and perspectives. Journal of Cultural Heritage, 10(1), pp. 1-8. DOI: 10.1016/j.culher.2008.09.002. 
[4] Mesquita, E., Arêde, A., Pinto, N., Antunes, P. and Varum, H. (2018). Long-term monitoring of a damaged historic structure using a wireless sensor network. Engineering Structures, 161, pp. 108-117.

DOI: 10.1016/j.engstruct.2018.02.013.

[5] Altunisik, A. C., Adanur, S., Genc, A. F., Gunaydin, M. and Okur, F. Y. (2017). An Investigation of the Seismic Behaviour of an Ancient Masonry Bastion Using Non-Destructive and Numerical Methods. Experimental Mechanics, 57(2), pp. 245-259. DOI: 10.1007/s11340-016-0239-x.

[6] Preciado, A. (2015). Seismic vulnerability and failure modes simulation of ancient masonry towers by validated virtual finite element models. Engineering Failure Analysis. 57, pp. 72-87. DOI:10.1016/j.engfailanal.2015.07.030.

[7] Theodossopoulos, D. and Sinha, B. (2013). A review of analytical methods in the current design processes and assessment of performance of masonry structures. Construction and Building Materials, 41, pp. 990-1001. DOI: 10.1016/j.conbuildmat.2012.07.095.

[8] Clementi, F., Gazzani, V., Poiani, M. and Lenci, S. (2016). Assessment of seismic behaviour of heritage masonry buildings using numerical modeling. Journal of Building Engineering, 8, pp. 29-47. DOI:10.1016/j.jobe.2016.09.005.

[9] Ortega, J., Vasconcelos, G., Lourenço, P. B., Rodrigues, H. and Varum, H. ed., (2015). Seismic vulnerability of vernacular buildings in urban centres-the case of Vila Real de Santo António. In: Seismic Retrofitting: Learning from Vernacular Architecture. London: Taylor and Fracis Group. pp. 219-226.

[10] Ceroni, F., Pecce, M., Sica, S. and Garofano, A. (2012). Assessment of Seismic Vulnerability of a Historical Masonry Building, Buildings. 2(3), pp. 332-358. DOI: 10.3390/buildings2030332.

[11] Endo, Y., Pelà, L., Roca, P., Porto, F. and Modena, C. (2015). Comparison of seismic analysis methods applied to a historical church struck by 2009 L'Aquila earthquake. Bulletin of Earthquake Engineering, 13(12), pp. 3749-3778. DOI: $10.1007 /$ s10518-015-9796-0.

[12] Wong, K. K. F. (2011). Seismic Applications of Nonlinear Response Spectra Based on the Theory of Modal Analysis. Procedia Engineering, 14, pp. 1645-1652. DOI: 10.1016/j.proeng.2011.07.207.

[13] Facchini, L. and Betti, M. (2017). Time-history analysis of slender masonry towers: a parametric study on the reliability of a simplified Bouc and Wen approach. Meccanica, 52(13), pp. 3181-3196. DOI: 10.1007/s11012-017-0671-8.

[14] Betti, M. and Vignoli, A. (2011). Numerical Assessment of the Static and Seismic Behaviour of the Basilica of Santa Maria all'Impruneta (Italy). Construction and Building Materials, 25(12), pp. 4308-4324.

DOI: $10.1016 /$ j.conbuildmat.2010.12.028.

[15] Castellazzi, G., Gentilini, C. and Nobile, L. (2013). Seismic vulnerability assessment of a historical church: limit analysis and nonlinear finite element analysis. Advances in Civil Engineering, 2013, pp. 4308-4324.

DOI: $10.1155 / 2013 / 517454$.

[16] Milani, G. (2013). Lesson learned after the Emilia Romagna, Italy, 20-29 May 2012 earthquakes: a limit analysis insight on three masonry churches. Engineering Failure Analysis, 34, pp. 761-768.

DOI: 10.1016/j.engfailanal.2013.01.001.

[17] Teixeira, W., Fairchild, T. R., Toledo, M. C. M. de and Taioli, F. (2000). Decifrando a terra. São Paulo: Oficina de Textos. (in Portuguese).

[18] Veloso, J. A. V. (2012). O terremoto que mexeu com o Brasil. Brasília: Thesaurus. (in Portuguese).

[19] Assumpção, M., Pirchiner, M., Dourado, J. C. and Barros, L. V. (2016). Terremotos no Brasil: Preparando-se para Eventos Raros. Bulletin of Brazilian Society of Geophysics. [online].

Available at: https://sbgf.org.br/home/images/Boletim_96-2016.pdf [Accessed 31 Jun. 2018]. (in Portuguese).

[20] Brazilian Association of Technical Standards. (2006). NBR 15421: Design of seismic resistant structures- Procedure. Rio de Janeiro: ABNT, pp. 7. (in Portuguese).

[21] Oliveira, P. H. S. (2015). Sismicidade e esforços tectônicos na Zona Sísmica Acaraú, Nordeste do Brasil. PhD Thesis. Federal University of Rio Grande do Norte. (in Portuguese).

[22] Betti, M., Galano, L. and Vignoli, A. ed., (2016). Finite element modelling for seismic assessment of historic masonry buildings. In: Earthquakes and their impact on society. Cham: Springer. p. 377-415.

DOI: 10.1007/978-3-319-21753-6_14.

[23] Betti, M., Galano, L. and Vignoli, A. (2008). Seismic response of masonry plane walls: a numerical study on spandrel strength. In: Seismic Engineering Conference Commemorating the 1908 Messina and Reggio Calabria Earthquake. Reggio Calabria: American Institute of Physics, pp. 787-794. DOI: 10.1063/1.2963915.

[24] Parisenti, R. (2011). Estudo de análise dinâmica e métodos da NBR-15421 para o projeto de edifícios submetidos a sismos. Master Dissertation. Federal University of Santa Catarina. (in Portuguese).

[25] Oliveira, P. H. S. (2010). Estudo da sismicidade na região de Sobral-CE em 2008. Master Dissertation. Federal University of Rio Grande do Norte. (in Portuguese). 
[26] Santos, S. H. C., Lima, S. S. and Silva, F. C. M. (2010). Seismic Hazard for Brazilian Northeastern Region. IBRACON Structures and Materials Journal, 3(3), pp. 374-389.

[27] Pinto, J. J. S. (2009). Os novos palácios da velha princesa: intervenções arquitetônicas contemporâneas no sitio histórico de Sobral. Master Dissertation. Federal University of Rio Grande do Norte. (in Portuguese).

[28] Brazilian Association of Technical Standards. (1980). NBR 6120: Loads for design of buildings structures. Rio de Janeiro: ABNT, pp. 3. (in Portuguese).

[29] Branco, M. E. M. (2007). Reforço Sísmico de Edifícios de Alvenaria Aplicação a edifícios “Gaioleiros”. Master Dissertation. Instituto Superior Técnico. (in Portuguese).

[30] Neves, S. M. L. C. (2008). Análise Sísmica de um Edifício da Baixa Pombalina. Master Dissertation. Instituto Superior Técnico. (in Portuguese).

[31] Italian Ministry of Infrastructures and Transport. (2008). Norme Tecniche per le Costruzioni (NTC 2008) D.M. del 14/01/2008. Rome: MIT, pp. 403 .(in Italian).

[32] Delgado, J. L. (2013). Avaliação sísmica de um edifício crítico em alvenaria. Master Dissertation. Instituto Superior Técnico. (in Portuguese).

[33] Frazão, M. T. B. R. F. (2013). Modelação de um edifício “gaioleiro” para avaliação e reforço sísmico. Master Dissertation. Instituto Superior Técnico. (in Portuguese).

[34] Gentile, C. and Saisi, A. (2007). Ambient vibration testing of historic masonry towers for structural identification and damage assessment. Construction and Building Materials, 21(6), pp. 1311-1321.

DOI: $10.1016 /$ j.conbuildmat.2006.01.007.

[35] Magalhães, F., Cunha, A., Caetano, E. (2012). Vibration based structural health monitoring of an arch bridge: From automated OMA to damage detection. Mechanical Systems and Signal Processing, 28, pp. 212-228.

DOI: $10.1016 /$ j.ymssp.2011.06.011.

[36] Ubertini, F., Gentile, C. and Materazzi, A. L. (2013). Automated modal identification in operational conditions and its application to bridges. Engineering Structures 46, pp. 264-278. DOI: 10.1016/j.engstruct.2012.07.031

[37] Gutiérrez, W. E. S., Vélez, C. G., Szwedowicz, W. D., Bedolla, H. J. and Cortés, G. C. (2013). Identificación de modos cercanos de vibración de una estructura cuasi-axisimétrica: estudio complementário. Ingeniería Investigación y Tecnología XIV(2), pp. 207-222. (in Spanish)

[38] Mesquita, E., Brandão, F., Diógenes, A., Antunes, P. and Varum, H. (2017). Ambient vibrational characterization of the Nossa Senhora das Dores Church. Engineering Structures and Technologies, 9(4), pp. 170-182. DOI: 10.3846/2029882X.2017.1416311.

[39] Brandão, F., Mesquita, E., Diógenes, A., Antunes, P. and Varum, H. (2018). Dynamic characterization of a heritage construction from 19th century. IBRACON Structures and Materials Journal, 11(7), pp. 52-75.

DOI: $10.1590 /$ S1983-41952018000100004.

[40] Betti, M., Boschi, S., Borghini, A., Ciavattone, A. and Vignoli, A. (2017). Comparative Seismic Risk Assessment of Basilica-type Churches. Journal of Earthquake Engineering, pp. 1-34. DOI: 10.1080/13632469.2017.1309602.

[41] Brandonisio, G., Lucibello, G., Mele, E. and De Luca A. (2013). Damage and performance evaluation of masonry churches in the 2009 L'Aquila earthquake. Engineering Failure Analysis, 34, pp. 693-714.

DOI: 10.1016/j.engfailanal.2013.01.021.

[42] Brandonisio, G., Lucibello, G., Mazziotti, A., Mele, E. and De Luca, A. (2015). Analisi di edifici monumentali ecclesiastici sotto azioni sismiche: problemi aperti. In: XVI Convegno Nazionale "L'Ingegneria Sismica in Italia". L'Aquila: ANIDIS, pp. 1-10. (in Italian)

[43] Gattulli, V., Antonacci and E., Vestroni, F. (2013). Field Observations and Failure Analysis of the Basilica S. Maria di Collemaggio after the 2009 L'Aquila Earthquake. Engineering Failure Analysis, 34, pp. 715-734.

DOI: $10.1016 /$ j.engfailanal.2013.01.020.

[44] Milani, G. (2013). Lesson learned after the Emilia Romagna, Italy, 20-29 May 2012 earthquakes: a limit analysis insight on three masonry churches. Engineering Failure Analysis, 34, pp. 761-768. DOI: $10.1016 /$ j.engfailanal.2013.01.001.

[45] Milani, G. and Valente, M. (2015). Comparative pushover and limit analyses on seven masonry churches damaged by the 2012 Emilia-Romagna (Italy) seismic events: Possibilities of non-linear finite elements compared with pre-assigned failure mechanisms. Engineering Failure Analysis, 47, pp. 129-161. DOI: 10.1016/j.engfailanal.2014.09.016.

[46] Milani, G. and Valente, M. (2015b). Failure analysis of seven masonry churches severely damaged during the 2012 Emilia-Romagna (Italy) earthquake: Non-linear dynamic analyses vs conventional static approaches. Engineering Failure Analysis, 54, pp. 13-56. DOI: 10.1016/j.engfailanal.2015.03.016. 
[47] Pieraccini, M., Betti, M., Forcellini, D., Devis, D., Papi, F., Bartoli, G., Facchini, L., Corazzi, R. and Kovacevic, C.V. (2017). Radar detection of pedestrian-induced vibrations of Michelangelo's David. Plos ONE, 12(4), pp. 1-20. DOI: $10.1371 /$ journal.pone.0174480

[48] Clementi, F., Gazzani, V., Poiani, M. and Lenci, S. (2016). Assessment of seismic behaviour of heritage masonry buildings using numerical modelling. Journal of Building Engineering, 8, pp. 29-47. DOI: 10.1016/j.jobe.2016.09.005.

[49] Yanez, C. P., Ramirez L. G., Ruiz, A. L. G., Delgado, R. D., Macias, M. C., Sandoval, H. G., Alcantara, L. N. and Quiroz, A. R. (2014). Strong Ground Motion Database System for the Mexican Seismic Network. [online] Available at: http://aplicaciones.iingen.unam.mx/AcelerogramasRSM/Inicio.aspx. [Accessed 31 Jun. 2018].

[50] Center for Engineering Strong Motion Date. (2013). CESMD Internet Data Report. [online] Available at: http://www.strongmotioncenter.org/cgibin/CESMD/iqr_dist_DM2.pl?IQRID=ElCentro_18May1940\&SFlag=0\&F lag=3. [Accessed 31 Jun. 2018]. 